\title{
Article \\ Neuroprotective Properties of Quinone Reductase 2 Inhibitor M-11, a 2-Mercaptobenzimidazole Derivative
}

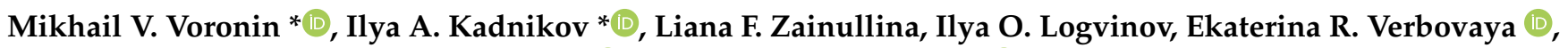 \\ Tatyana A. Antipova, Yulia V. Vakhitova *(D) and Sergei B. Seredenin *(i) \\ Department of Pharmacogenetics, Federal State Budgetary Institution “Research Zakusov Institute of \\ Pharmacology", Baltiyskaya Street 8, 125315 Moscow, Russia; zainullinalf@gmail.com (L.F.Z.); \\ logvinov_ilya@mail.ru (I.O.L.); zueva.kate1997@gmail.com (E.R.V.); zenina_tatyana@mail.ru (T.A.A.) \\ * Correspondence: dnamed@mail.ru (M.V.V.); ikadnikov@gmail.com (I.A.K.); juvv73@gmail.com (Y.V.V.); \\ seredeninpharm@mail.ru (S.B.S.); Tel.: +7-(499)-1511881 (S.B.S.)
}

Citation: Voronin, M.V.; Kadnikov, I.A.; Zainullina, L.F.; Logvinov, I.O.; Verbovaya, E.R.; Antipova, T.A.; Vakhitova, Y.V.; Seredenin, S.B. Neuroprotective Properties of Quinone Reductase 2 Inhibitor M-11, a 2-Mercaptobenzimidazole Derivative Int. J. Mol. Sci. 2021, 22, 13061. https://doi.org/10.3390/ ijms222313061

Academic Editor: Michael Ugrumov

Received: 19 November 2021 Accepted: 29 November 2021 Published: 2 December 2021

Publisher's Note: MDPI stays neutral with regard to jurisdictional claims in published maps and institutional affiliations.

Copyright: (c) 2021 by the authors. Licensee MDPI, Basel, Switzerland. This article is an open access article distributed under the terms and conditions of the Creative Commons Attribution (CC BY) license (https:/ / creativecommons.org/licenses/by/ $4.0 /)$.

\begin{abstract}
The ability of NQO2 to increase the production of free radicals under enhanced generation of quinone derivatives of catecholamines is considered to be a component of neurodegenerative disease pathogenesis. The present study aimed to investigate the neuroprotective mechanisms of original NQO2 inhibitor M-11 (2-[2-(3-oxomorpholin-4-il)-ethylthio]-5-ethoxybenzimidazole hydrochloride) in a cellular damage model using NQO2 endogenous substrate adrenochrome $(125 \mu \mathrm{M})$ and co-substrate BNAH $(100 \mu \mathrm{M})$. The effects of M-11 $(10-100 \mu \mathrm{M})$ on the reactive oxygen species (ROS) generation, apoptosis and lesion of nuclear DNA were evaluated using flow cytometry and single-cell gel electrophoresis assay (comet assay). Results were compared with S29434, the reference inhibitor of NQO2. It was found that treatment of HT-22 cells with M-11 results in a decline of ROS production triggered by incubation of cells with NQO2 substrate and co-substrate. Pre-incubation of HT-22 cells with compounds M-11 or S29434 results in a decrease of DNA damage and late apoptotic cell percentage reduction. The obtained results provide a rationale for further development of the M-11 compound as a potential neuroprotective agent.
\end{abstract}

Keywords: NQO2; adrenochrome; BNAH; ROS; comet assay; apoptosis; HT-22 cells; NQO2 inhibitors; 2-mercaptobenzimidazole derivative; S29434

\section{Introduction}

Epidemiological data indicate an increasing prevalence of neurodegenerative diseases, especially in countries with high life expectancy [1]. Pathogenesis of Alzheimer's, Parkinson's and Huntington's diseases include imbalance of cellular bioenergetics, increased ROS production, protein misfolding resulting in neuron and glial cells loss, synaptic deterioration and decreased neuroplasticity [2-4], which determine physiological function impairment and clinical symptoms [5]. Oxidative stress is considered to be the main mechanism damaging pivotal cell macromolecules [6-9]. Numerous reviews and monographs have described causes and sources of overproduction of free radicals [10-12]. Extensive information on natural and synthesized antioxidant use for central nervous system disease treatment has been accumulated [13,14]. However, their pharmacotherapeutic use requires further elaboration based on the study of pathogenetic mechanisms $[15,16]$.

Disturbances in the metabolism of catecholamines with excessive production of their quinone derivatives and reactive oxygen species (ROS) provide a significant contribution to the oxidative stress [17-24]. For example, dopamine, a precursor of other neurotransmitter catecholamines, after being synthesized in the cytosol, is transported to synaptic vesicles by the synaptic vesicular amine transporter (VAT2; VMAT2) with the participation of V-type proton ATPase (V-ATPase) and glyceraldehyde-3-phosphate dehydrogenase (GAPDH) $[25,26]$. V-ATPase-dependent proton gradient provides a $\mathrm{pH}$ of $\sim 5.6$ in synaptic vesicles which ensures stability of catecholamines [27]. However, in neurodegenerative diseases, oxidative modification 
of GAPDH [28] mediates impairments to the functional activity of VAT2 [29], leading to a decreased uptake of catecholamines to vesicles both after presynaptic reuptake or de novo synthesis $[30,31]$ and their autoxidation to quinones at $\mathrm{pH} 7.4[27,32]$. Quinone derivatives of catecholamines, possessing electrophilic properties, form conjugates with $\mathrm{NH} 2$-groups of amino acid residues of proteins and nucleic acid bases, disrupting their native conformation and functional activity [33-35].

Flavin-dependent enzyme ribosyldihydronicotinamide dehydrogenase [quinone] (NQO2; QR2) is involved in the detoxification of quinone derivatives of catecholamines, catalyzing a two-electron reduction of para-quinones (1,4-quinones), ortho-quinones (1,2quinones) and pseudoquinones [36,37]. However, the quinols (hydroquinones) formed during the enzymatic reaction undergo autooxidation to semiquinones [36,38,39], which are capable of transferring their unpaired electron to other oxidants, including molecular oxygen [40] (Figure 1). The reaction produces superoxide anion radicals $\left(\mathrm{O}_{2}{ }^{-}-\right)$and the corresponding quinone [38-41]. In addition, semiquinones can interact with each other to form quinone and initial quinol [42]. Reduction of quinone, catalyzed by $\mathrm{NQ}_{\mathrm{O} 2}$, renews the redox cycle [43] (Figure 1).

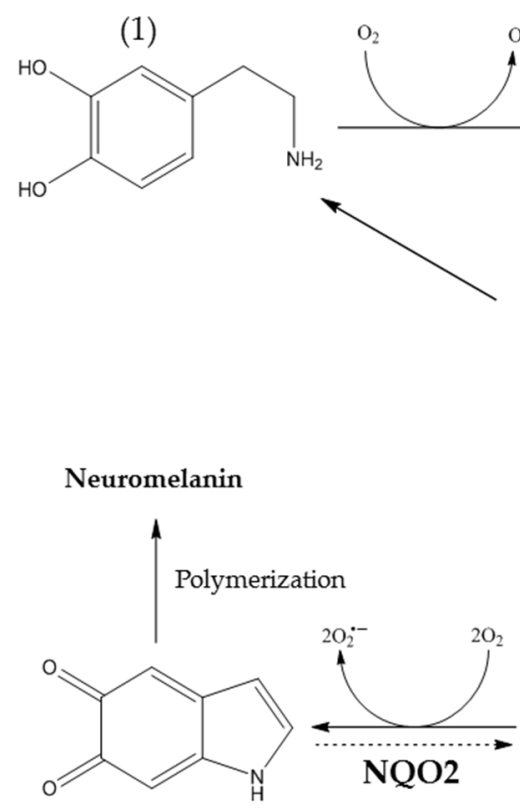

(7)
(2)<smiles>NCCc1ccc(O)c(O)c1</smiles>

Disproportionation
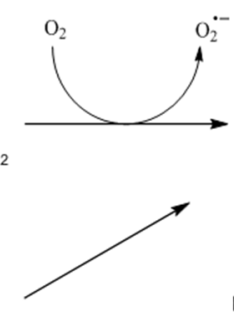

(4)<smiles>NCCC1=CC(=O)C(=O)C(c2c(O)c(O)cc3c2CCN3)=C1</smiles>

(6)

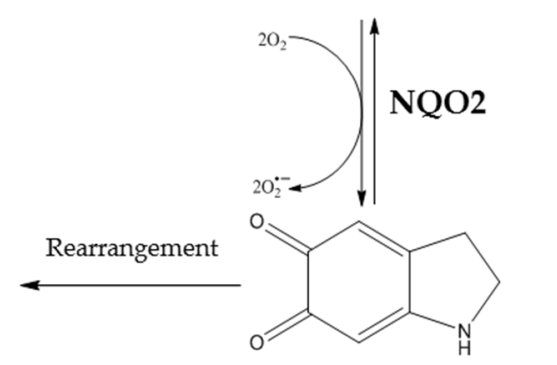

(5)

Figure 1. Oxidation of dopamine as a possible source of NQO2 endogenous substrates. The scheme is based on Segura-Aguilar et al. [42] and Cassagnes et al. [44]. (1)-dopamine, (2)-dopamine semiquinone, (3)-dopamine o-quinone, (4)-leukoaminochrome, (5)-aminochrome, (6)-5,6-dihydroxyindole, (7)-5,6-indolequinone. Synthesis of (3), (5) and (7) passes through formation of respective semiquinones that may undergo disproportionation reaction when two identical semiquinones interact, generating respective quinone and hydroquinone. A dashed arrow corresponds to the putative reaction that is catalyzed by $\mathrm{NQO} 2$.

Thus, in neurodegenerative diseases under conditions of insufficient antioxidant systems $[45,46]$, these reactions lead to an increase in the production of free radicals. Therefore, it can be assumed that a therapeutic effect is achieved due to a decrease in NQO2 activity $[39,47,48]$.

NQO2 is expressed in different regions of the human brain $[49,50]$ and is predominantly localized in cell cytosol [36]; the existence of $\mathrm{NQO} 2$ in nucleoplasm was also observed [50,51]. Human NQO2 consists of 231 amino acid residues (26 kDa) [52] and includes catalytic (1-220 aa) and C-terminal domains (221-231 aa) [53]. After cloning the NQO2 gene, determining the amino acid sequence of the enzyme [52], as well as analysis of ligand binding $[54,55]$ revealed the NQO2 regulatory site to be designated as 
an $\mathrm{MT}_{3}$ receptor [56]. Known ligands of the $\mathrm{MT}_{3}$ receptor are melatonin and its derivatives [57], benzimidazole derivatives TBB, TBBz, DMAT [58], flavonoids resveratrol [59] and quercetin [60], $\alpha$-adrenergic receptor antagonist prazosin [61] inhibit NQO2 [36] and possess neuroprotective properties. However, these compounds are not selective ligands of the $\mathrm{MT}_{3}$ receptor, and its mechanisms of neuroprotective action include other molecular targets [62-66].

During pharmacokinetic studies of anxiolytic afobazole (ethoxy-2-[2-(morpholino)ethylthio]benzimidazole dihydrochloride) [67], interacting with chaperone Sigma1R $(\mathrm{Ki}=5.9 \mu \mathrm{M}), \mathrm{NQO} 2\left(\mathrm{MT}_{3}\right.$ receptor, $\left.\mathrm{Ki}=0.97 \mu \mathrm{M}\right)$ and monoamine oxidase A (MAO-A, $\mathrm{Ki}$ $=3.6 \mu \mathrm{M})$ regulatory sites [68], carried out at the FSBI "Zakusov Institute of Pharmacology", a metabolite of afobazole 2-[2-(3-oxomorpholine-4-yl)ethylthio]-5-ethoxybenzimidazole hydrochloride (M-11) was found [69,70]. Radioligand analysis (Eurofins Cerep) have indicated that compound $\mathrm{M}-11$ interacts only with the $\mathrm{NQO} 2$ regulatory site $(\mathrm{Ki}=0,39 \mu \mathrm{M})[68]$. We have shown that M-11 inhibits NQO2 [71], and possesses cytoprotective [72,73] and neuroprotective [74] effects. Our experiments did not reveal any influence of M-11 on the effects related to the activity of homologous enzyme NQO1 (Figure A1) [72,75].

Single-cell gel electrophoresis assay, also known as comet assay, allows one to evaluate nuclear DNA damage as a consequence of oxidative stress [76,77]. An increase in the amount of DNA in the comet tail reflects the generation of alkali-labile sites (apurinic/apyrimidinic sites) and DNA strand breaks [78]. However, morphologically atypical comets (hedgehog comets, cloud comets, ghost cells, high damage cells) can be observed and, generally, this type of comet is not taken into account during analysis. It should be noted that oxidative stress is considered as one of mechanisms contributing to the formation of atypical comets, which was demonstrated in the presence of high concentrations of $\mathrm{H}_{2} \mathrm{O}_{2}[79,80]$.

In this study, we took advantage of the in vitro experimental model, by using the endogenous NQO2 substrate adrenochrome and co-substrate BNAH to evaluate the mechanisms of neuroprotective activity of M-11 based on analysis of ROS-triggered apoptosis and oxidative nuclear DNA damage assessed by comet assay. The effects of M-11 were compared with S29434, a known NQO2 inhibitor [81].

\section{Results}

We used HT-22 cells treated with NQO2 endogenous substrate adrenochrome and co-substrate BNAH as an in vitro model for NQO2-mediated ROS production, since HT-22 cells express NQO2 [82] (Figure S1) and NQO2 has been shown to be capable of producing ROS in reaction with the aforementioned substrate and co-substrate [43]. Incubation of HT22 cells with adrenochrome (50-200 $\mu \mathrm{M}$ concentration range) and BNAH $(100 \mu \mathrm{M})$ causes a statistically significant increase in the CellROX Green signal for sub-cellular superoxide $\left(\mathrm{O}_{2}{ }^{\bullet-}\right)$ with maximum fluorescence at $125 \mu \mathrm{M}$ of adrenochrome (Figure 2) compared to control cells («adrenochrome $(0 \mu \mathrm{M})+$ BNAH group»). General ROS levels detected using $\mathrm{CM}-\mathrm{H}_{2}$ DCFDA dye, showed an increase in a concentration-dependent manner with the maximum of fluorescence values at 125-200 $\mu \mathrm{M}$ of adrenochrome (Figure 2). Thus, a 125 $\mu \mathrm{M}$ concentration of adrenochrome has proven to be the most active in these assays and was used for subsequent experiment series with studied compounds.

Pre-incubation of cells for 30 min with M-11 or S29434 prevented the oxidative stress caused by 15 min incubation with adrenochrome $(125 \mu \mathrm{M})$ and BNAH $(100 \mu \mathrm{M})$ in a concentration-dependent manner (Figure 3). In particular, pre-treatment of cells with M-11 followed by adrenochrome + BNAH incubation led to a decrease in CellROX Green Reagent $(p<0.001)$ and $\mathrm{CM}-\mathrm{H}_{2}$ DCFDA $(p<0.05)$ fluorescence at $100 \mu \mathrm{M}$ of $\mathrm{M}-11$ compared to control cells («adrenochrome + BNAH group») (Figure 3a). Compound S29434 attenuated CellROX Green Reagent fluorescence at concentrations of $25 \mu \mathrm{M}(p<0.01)$ and $50 \mu \mathrm{M}(p$ $<0.001)$, while a decrease in CM- $\mathrm{H}_{2}$ DCFDA fluorescence was detected at concentrations of $10 \mu \mathrm{M}(p<0.05), 25 \mu \mathrm{M}(p<0.01)$ and $50 \mu \mathrm{M}(p<0.001)$ compared to control cells («adrenochrome + BNAH group») (Figure $3 b$ ). 


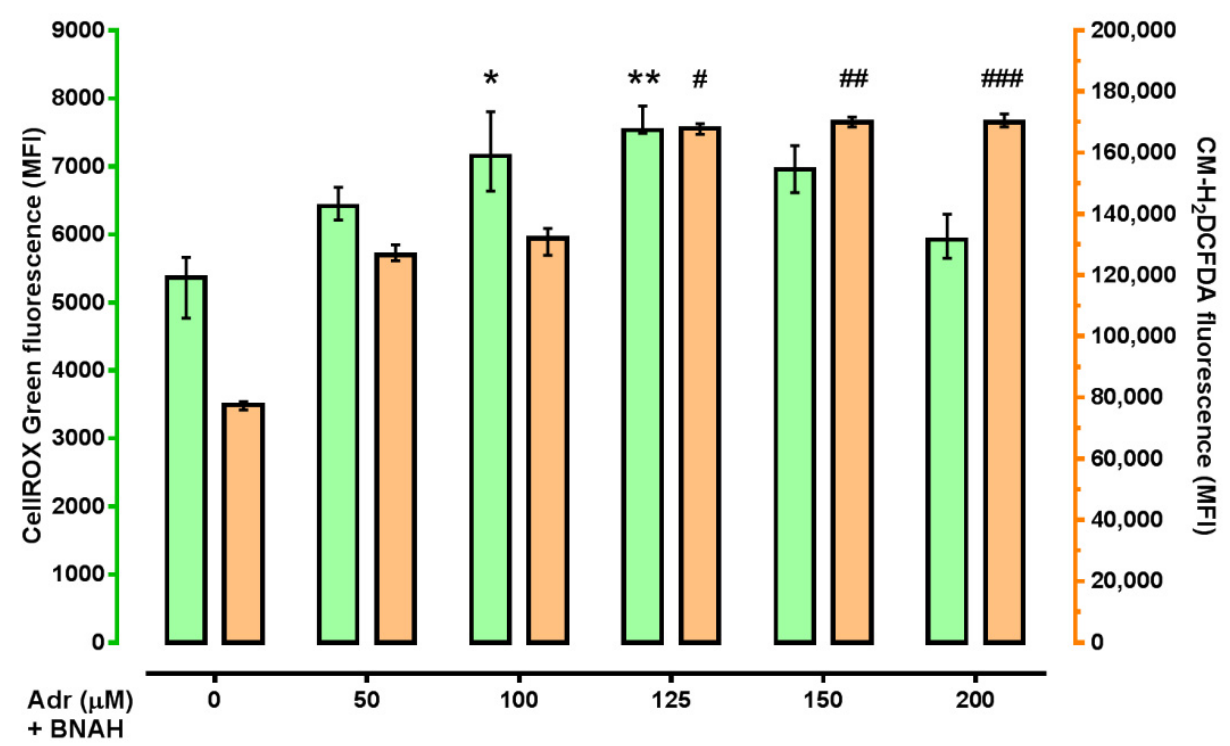

Figure 2. The effect of adrenochrome and BNAH on ROS production in HT-22 cells. Cells were incubated with adrenochrome $(50-200 \mu \mathrm{M})$ and/or BNAH $(100 \mu \mathrm{M})$ for 15 min. Final concentration of DMSO was $0.2 \%$. Data are presented as median (min-max). All experiments were performed in 12 replicates. Kruskal-Wallis test with Dunn's post-hoc: ${ }^{*} p<0.05,{ }^{* *} p<0.01$ vs. Adrenochrome $(0 \mu \mathrm{M})+$ BNAH group in ROS measurement with CellROX Green Reagent; \# $p<0.05, \# \# p=0.003$, $\# \# \#<0.001$ vs. Adrenochrome $(0 \mu \mathrm{M})+$ BNAH group in ROS measurement with $\mathrm{CM}-\mathrm{H}_{2}$ DCFDA. For details see Table S1.

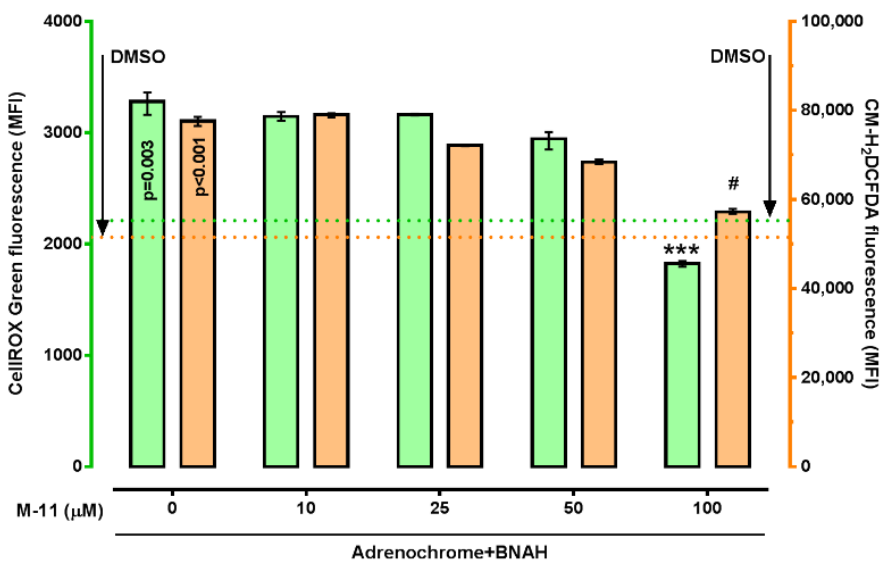

(a)

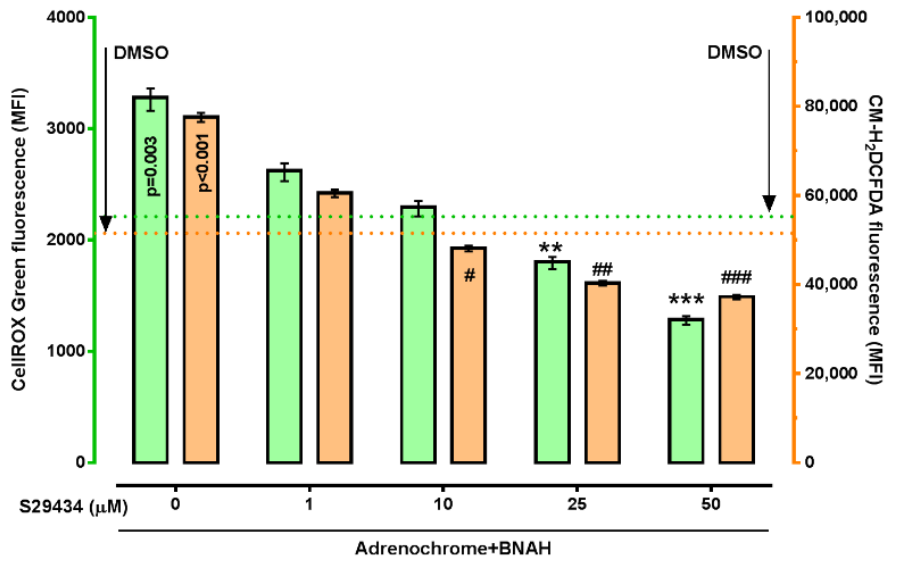

(b)

Figure 3. The effect of NQO2 inhibitors on the level of ROS elicited by adrenochrome and BNAH in HT-22 cells. Cells were pre-incubated with M-11 (10-100 $\mu \mathrm{M})(\mathbf{a})$ or S29434 (1-50 $\mu \mathrm{M})(\mathbf{b})$ for $30 \mathrm{~min}$, following incubation with a combination of adrenochrome $(125 \mu \mathrm{M})$ and BNAH $(100 \mu \mathrm{M})$ for $15 \mathrm{~min}$. All experiments were performed in 9 replicates. Data are presented as median (min-max). Kruskal-Wallis test with Dunn's post-hoc: ${ }^{* *} p<0.01,{ }^{* * *} p<0.001$ vs. M-11 (0 $\left.\mu \mathrm{M}\right)$ or S29434 $(0 \mu \mathrm{M})+$ adrenochrome/BNAH group in ROS measurement with CellROX Green Reagent; \# $p<0.05$, \#\# $p<0.01$, \#\#\# $p<0.001$ vs. M-11 $(0 \mu \mathrm{M})$ or S29434 $(0 \mu \mathrm{M})+$ adrenochrome/BNAH group in ROS measurement with CM-H ${ }_{2}$ DCFDA. $p=0.03, p<0.001$ - statistical significance vs. corresponding DMSO groups. For details see Table S2.

These data demonstrate both an increase in ROS production upon HT-22 cells incubation with the NQO2 substrate and co-substrate, and the ability of the M-11 compound, as well as the reference NQO2 inhibitor S29434, to reduce the production of ROS.

In the following series of experiments, the concentration and time dependences of endogenous NQO2 substrate adrenochrome effects on nuclear DNA damage of HT-22 cells were characterized (Figure 4). Adrenochrome at 100, 150 and $200 \mu \mathrm{M}$ concentrations 
increased the percentage of DNA in the tail of typical comets (Figure S2) in all selected time ranges of co-incubation with BNAH $(100 \mu \mathrm{M})$ (Figure 4). Levels of atypical DNA comets (Figure S2) increased after 60, 90 and 120 min of cell co-incubation with adrenochrome at 150 and $200 \mu \mathrm{M}$ concentrations and BNAH $(100 \mu \mathrm{M})$ (Figure 4).

A two-way ANOVA test revealed the dependence of incubation time with adrenochrome and BNAH ( $\mathrm{F}=8.53, p<0.001)$ or adrenochrome concentration $(\mathrm{F}=360.8, p<0.001)$ on the percentage of DNA in the comet tail. At the same time, there was no relationship between these factors $(\mathrm{F}=0.61, p=0.78)$. Adrenochrome at 150 and $200 \mu \mathrm{M}$ concentrations increased the percentage of DNA in the comet tail compared to the corresponding incubation time at 50 or $100 \mu \mathrm{M}$. An increase in adrenochrome concentration from 150 to $200 \mu \mathrm{M}$ leads to a higher percentage of DNA in the comet tail only for $90 \mathrm{~min}$ incubation time (Figure 4).

A two-way ANOVA test of intergroup differences in the percentage of atypical comets was carried out for adrenochrome concentrations of 150 and $200 \mu \mathrm{M}$, which produced atypical comets at all incubation time points. Production of atypical comets depended on the incubation time $(\mathrm{F}=23.26, p<0.001)$ or adrenochrome concentration $(\mathrm{F}=16.48$, $p<0.001)$. There was no relationship between these factors $(\mathrm{F}=0.59, p=0.62)$. Adrenochrome (150 and $200 \mu \mathrm{M}$ ) at 60-120 min exposure caused a similar increase in the percentage of atypical comets compared to $30 \mathrm{~min}$ incubation times (Figure 4).

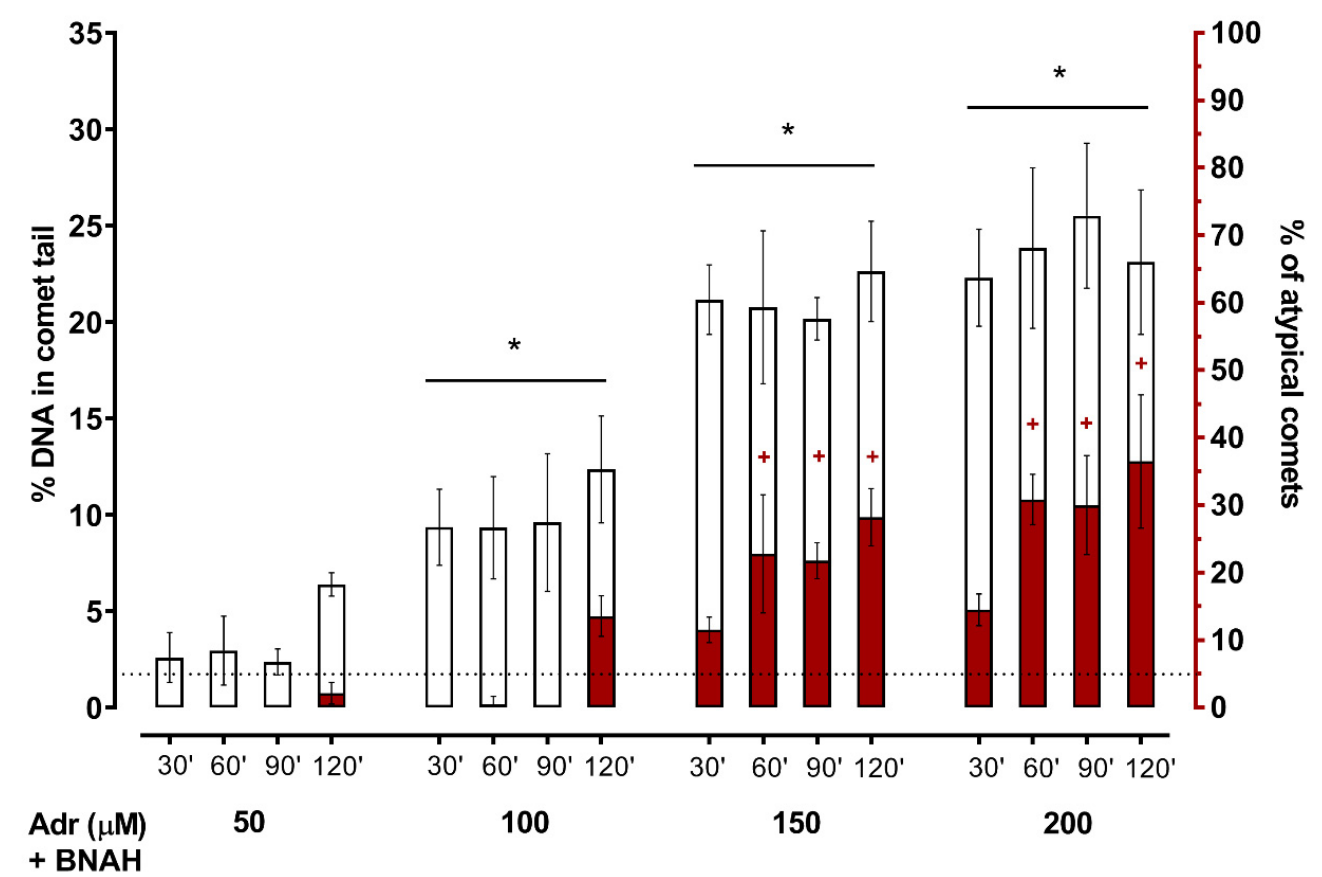

Figure 4. Time and concentration dependencies on DNA damage caused by adrenochrome and BNAH in HT-22 cells. Cells were incubated with adrenochrome $(50-200 \mu \mathrm{M})$ and BNAH $(100 \mu \mathrm{M})$ for 30, 60, 90 and $120 \mathrm{~min}$. Adrenochrome and BNAH were dissolved in DMSO, final concentration of DMSO was 2\%. All experiments were performed in 6 replicates. Data are presented as mean \pm S.D. Data on the percentage of DNA in the comet tail (blank bars) were evaluated using one-way ANOVA with Tukey's post-hoc: ${ }^{*} p<0.001$ vs. DMSO (dotted line). Data on the percentage of atypical comets (red bars) were evaluated using Kruskal-Wallis test with Dunn's post-hoc: $+p<0.05$ vs. DMSO. For details see Table S3.

Considering the ROS production results assessment (Figure 2) and levels of DNA damage caused by co-incubation of cells with the substrate and co-substrate NQO2 (Figure 4), a $125 \mu \mathrm{M}$ concentration of adrenochrome and a $30 \mathrm{~min}$ incubation time were chosen for a quantitative analysis of the effect of NQO2 inhibitors on the nuclear DNA damage of HT-22 cells (Figure 5). Such conditions provide a maximum percentage of DNA in the comet tail, while lacking atypical DNA comets (Figure 4). Incubation of cells with adrenochrome and BNAH for $30 \mathrm{~min}$ results in a more than fivefold increase in the average percentage of comet-tail DNA compared to the control groups (Figure S3, Table S4). In the absence of the NQO2 co-substrate BNAH, 
adrenochrome was unable to affect the comet tail DNA percentage versus vehicle (DMSO), but increased DNA damage versus intact control (intact cells). DMSO or BNAH did not change the percentage of DNA in the comet tail compared to the intact control (Figure S3, Table S4).

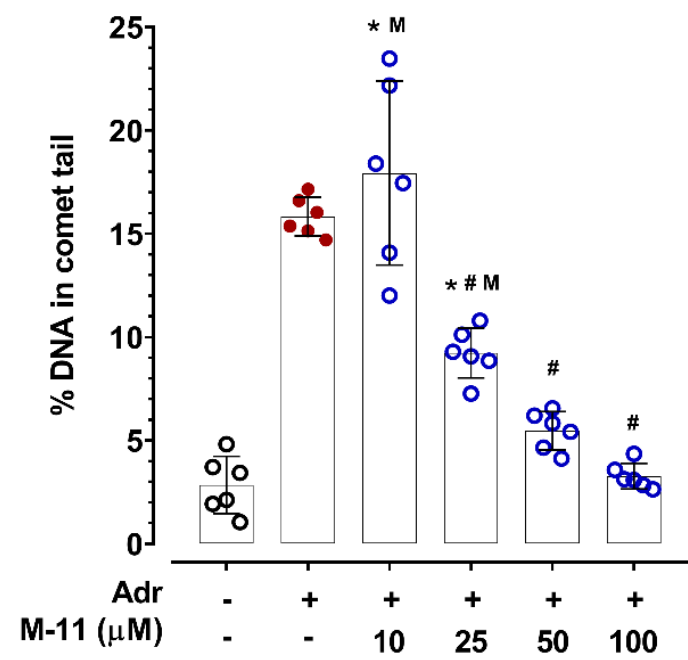

(a)

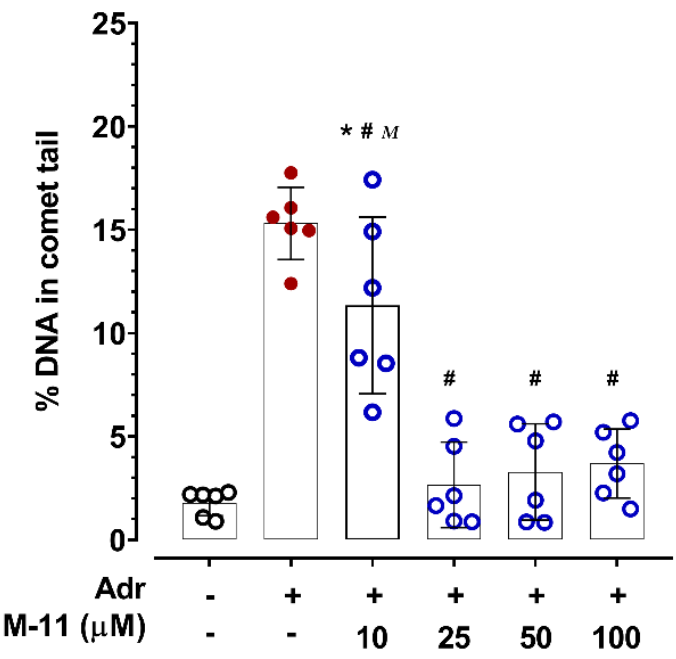

(c)

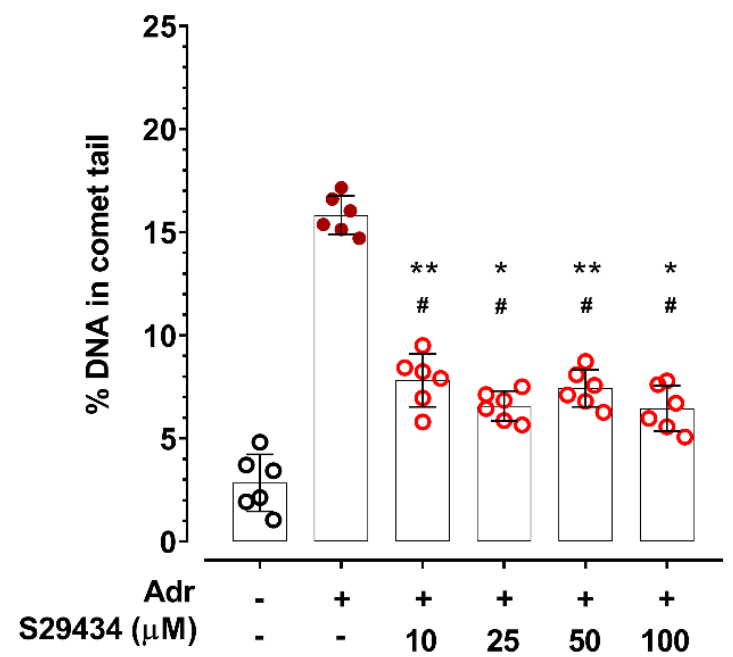

(b)

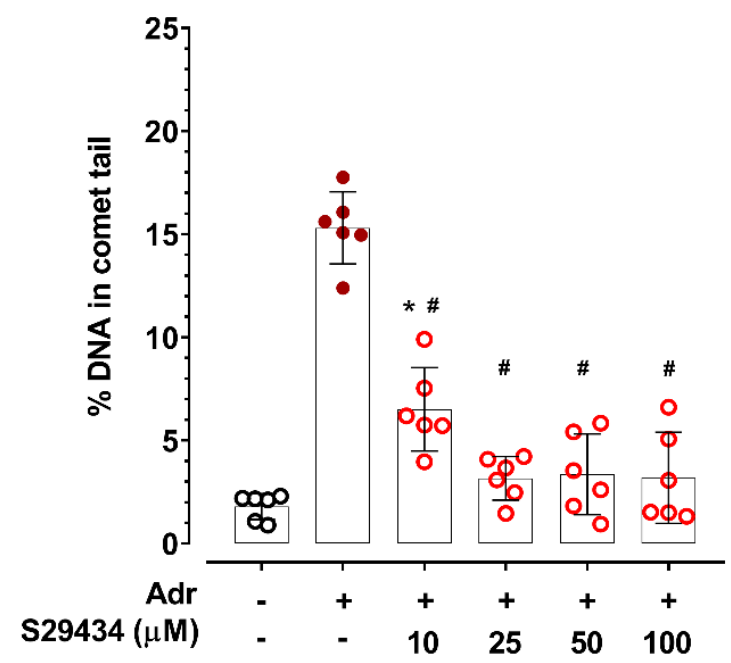

(d)

Figure 5. The influence of pre-incubation with NQO2 inhibitors on nuclear DNA damage of HT-22 cells caused by adrenochrome and BNAH. After pre-incubation with inhibitors for 30 or $45 \mathrm{~min}$, cells were exposed to adrenochrome (Adr $125 \mu \mathrm{M})$ and BNAH $(100 \mu \mathrm{M})$ for $30 \mathrm{~min}$. Adrenochrome and BNAH were dissolved in DMSO, final concentration of DMSO was $2 \%$. Data are presented as mean \pm S.D. Experimental data were analyzed by one-way ANOVA, Tukey's multiple comparison test. The percentage of DNA in the comet tail of cells incubated with Adr and BNAH was significantly higher versus the DMSO group (Adr-/inhibitor-) with $p<0.01$. (a) Influence of 30 min pre-incubation with M-11 on nuclear DNA damage $(10-100 \mu \mathrm{M}) .{ }^{*} p<0.01$ vs. DMSO; $p<0.0$ vs. Adr+/M-11-; ${ }^{\mathrm{M}} p<0.01$ vs. other concentrations of M-11; (b) influence of $30 \mathrm{~min}$ pre-incubation with S29434 on nuclear DNA damage $(10-100 \mu \mathrm{M}) .{ }^{*} p<0.05,{ }^{* *} p<0.01 \mathrm{vs}$. DMSO; \# $p<0.01$ vs. Adr+/S29434-; (c) influence of 45 min pre-incubation with M-11 on nuclear DNA damage $(10-100 \mu \mathrm{M})$. ${ }^{*} p<0.01$ vs. DMSO; \# $p<0.01$ vs. Adr $+/ \mathrm{M}-11-;{ }^{\mathrm{M}} p<0.01$ vs. other concentrations of M-11; (d) influence of 45 min pre-incubation with S29434 (10-100 $\mu \mathrm{M}) .{ }^{*} p<0.01$ vs. DMSO; \# $p<0.01$ vs. Adr+/S29434-. For details see Table S6.

Analysis of the concentration dependence of inhibitor action under the selected experimental conditions showed that 30 min pre-incubation of cells with the M-11 compound at 25,50 and $100 \mu \mathrm{M}$ concentrations reduces the damage to cell DNA caused by incubation with adrenochrome and BNAH (Figure 5a). Concentrations of 50 and $100 \mu \mathrm{M}$ of the M-11 
compound reduced comet-tail DNA percentage to control values. Under the same experimental conditions, the NQO2 inhibitor S29434 significantly reduced the percentage of comet-tail DNA in the whole range of concentrations $(10-100 \mu \mathrm{M})$; however, no differences with the control group were observed (Figure 5b). Thus, it was found that after $30 \mathrm{~min}$ of HT-22 cells pre-incubation with NQO2 inhibitors, the protective effect of M-11 at 50 and $100 \mu \mathrm{M}$ concentrations on DNA prevails over the effect of S29434, but is inferior at $10 \mu \mathrm{M}$ (Figure 5a,b).

An increase in the pre-incubation time with NQO2 inhibitors to 45 min enhances their protective effect on nuclear DNA of HT-22 cells (Figure $5 c$,d). All used concentrations of M11 significantly reduced cell DNA damage caused by $30 \mathrm{~min}$ incubation with adrenochrome and BNAH (Figure 5c). The compound M-11 at concentrations of 25, 50 and $100 \mu \mathrm{M}$ reduced the percentage of DNA in the comet tail to control values. Similar to M-11, $10 \mu \mathrm{M}$ concentration of S29434 reduced the percentage of comet-tail DNA, while 25, 50 and $100 \mu \mathrm{M}$ concentrations prevented nuclear DNA damage of HT-22 cells caused by incubation with adrenochrome and BNAH (Figure 5d). In control experiments, M-11 and S29434 did not affect DNA damage in HT-22 cells at a maximum concentration of $100 \mu \mathrm{M}$ in the absence of adrenochrome and BNAH in the incubation medium (Table S5).

In the further study of the M-11 compound's effect on DNA damage, a long-term incubation (120 min) of HT-22 cells with adrenochrome and BNAH was performed, where, in addition to typical DNA comets, atypical comets were registered, reflecting a higher degree of DNA fragmentation. The addition of $125 \mu \mathrm{M}$ or $200 \mu \mathrm{M}$ of adrenochrome to the incubation media significantly increased the percentage of DNA in the comet tail and the number of atypical DNA comets compared to the control group (DMSO) (Figure 6).

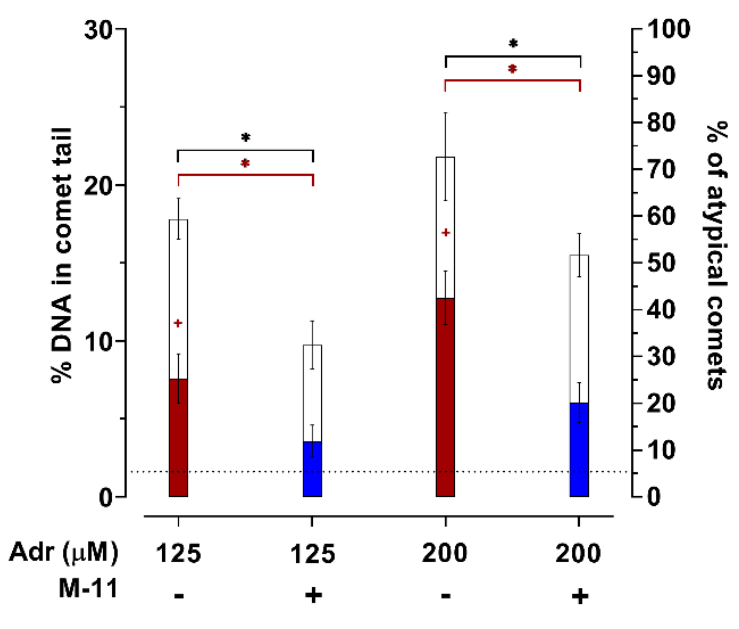

(a)

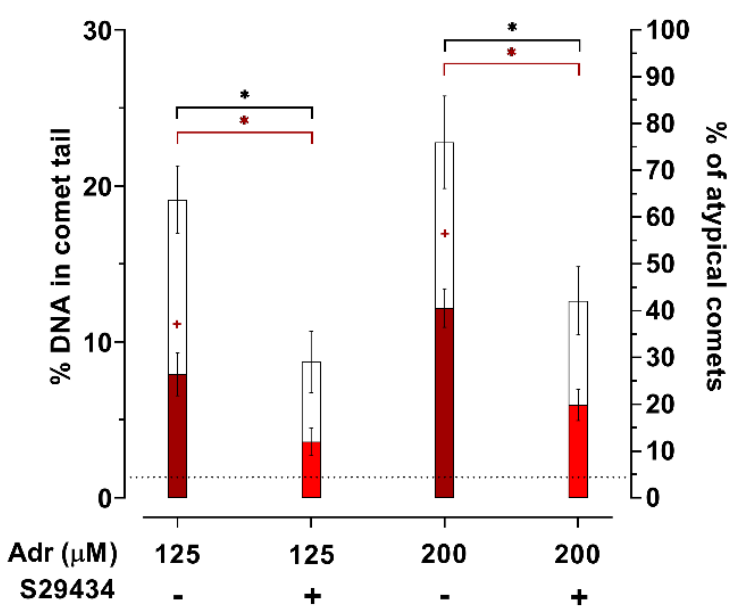

(b)

Figure 6. The influence of pre-incubation with NQO2 inhibitors on nuclear DNA damage of HT-22 cells exposed to adrenochrome and BNAH for $120 \mathrm{~min}$. Cells were pre-incubated with M-11 (a) or S29434 (b) (100 $\mu \mathrm{M})$ for $30 \mathrm{~min}$, and then were exposed to adrenochrome $(125$ or $200 \mu \mathrm{M})$ and BNAH $(100 \mu \mathrm{M})$ for $120 \mathrm{~min}$. Adrenochrome and BNAH were dissolved in DMSO. Final concentration of DMSO was 2\%. All experiments were performed in 6 replicates. Data are presented as mean \pm S.D. The percentage of DNA in the comet tail (blank bars) of cells exposed to adrenochrome and BNAH was significantly higher than DMSO (dotted line) with $p<0.001$ (one-way ANOVA with Tukey's post-hoc). Data on the percentage of atypical comets (colored bars) were evaluated using Kruskal-Wallis test with Dunn's post-hoc: $+p<$ 0.01 vs. DMSO. To evaluate the differences between groups exposed to adrenochrome and BNAH, two-way ANOVA with Tukey's post-hoc was used: * $p<0.001$ vs. pre-incubation with M-11 or S29434. For details see Tables S7 and S8.

Significant effects of adrenochrome concentration ( $\mathrm{F}=40.66, p<0.001$ for Figure 6a; $\mathrm{F}$ $=40.39, p<0.001$ for Figure $6 \mathrm{~b})$, pre-incubation with M-11 $(\mathrm{F}=88.75, p<0.001)$ or S29434 $(\mathrm{F}=81.37, p<0.001)$ on the percentage of DNA in the comet tail were observed. There was no relationship between these factors $(\mathrm{F}=1.33, p=0.26$ for Figure $6 \mathrm{a} ; \mathrm{F}=0.89, p=0.42$ for 
Figure $6 \mathrm{~b}$ ). Similar to experiments with 30 or 45 min pre-incubation (Figure 6), $100 \mu \mathrm{M}$ of M-11 or S29434 were also effective at $120 \mathrm{~min}$ incubation with BNAH and adrenochrome at $125 \mu \mathrm{M}$, significantly reducing the percentage of DNA in the comet tail (Figure 6). M-11 and S29434 had the same effect on the percentage of comet-tail DNA after 120 min incubation with BNAH and adrenochrome at a $200 \mu \mathrm{M}$ concentration (Figure 6).

Two-way ANOVA test revealed significant effects of adrenochrome concentration $(\mathrm{F}=$ 42.78, $p<0.001$ for Figure 6a; $\mathrm{F}=50.00, p<0.001$ for Figure 6b), pre-incubation with M-11 $(\mathrm{F}=84.96, p<0.001)$ or S29434 $(\mathrm{F}=127.3, p<0.001)$ on the percentage of atypical comets. The interaction between adrenochrome concentration and pre-incubation with M-11 was statistically significant $(\mathrm{F}=5.38, p=0.031)$, whereas this interaction for $\mathrm{S} 29434$ was not observed $(\mathrm{F}=4.03, p=0.058)$. M-11 and $\mathrm{S} 29434$ significantly reduced the percentage of atypical comets under conditions of 120 min incubation of HT-22 cells with BNAH and adrenochrome at both concentrations, leveling out statistically significant differences from the control group (Figure 6).

Thus, the ability of M-11 and S29434 to reduce both the percentage of DNA in the tail of typical comets and the number of atypical comets specific to long-term incubation of HT-22 cells with high concentrations of adrenochrome has been established.

Additionally, an apoptosis analysis was carried out using Annexin V/PI staining to corroborate the protective properties of M-11 in an adrenochrome/BNAH-induced cell damaging model. HT-22 cells were pre-treated with M-11 $(100 \mu \mathrm{M})$ or S29434 $(25 \mu \mathrm{M})$ for $45 \mathrm{~min}$ and afterwards exposed to adrenochrome $(125 \mu \mathrm{M})$ and BNAH $(100 \mu \mathrm{M})$ for 120 min. A significant increase in both early $(p<0.001)$ and late $(p<0.001)$ apoptosis rates was observed following cell treatment with adrenochrome/BNAH (Table 1). M-11 has been shown to decrease the percentage of late apoptotic cells, with no substantial effect on the number of early apoptotic cells, thus indicating that M-11 protects HT-22 cells from adrenochrome/BNAH-initiated apoptosis. Incubation of HT-22 with NQO2 inhibitor S29434 under similar experimental conditions resulted in a more considerable reduction of percentage of late apoptotic cells $(p<0.001)$, while no changes in the number of early apoptotic cells were mentioned. Importantly, M-11, as well as S29434, did not alter the percentage of early and late apoptotic cells when adrenochrome/BNAH were omitted, highlighting compounds' failure to affect apoptosis in the absence of cell damage.

Table 1. The impact of M-11 and S29434 on apoptosis of HT-22 cells treated with adrenochrome and BNAH.

\begin{tabular}{ccc}
\hline & \multicolumn{2}{c}{ Apoptotic Stages (\% of Cells) } \\
& Early & Late \\
\hline 0.3\% DMSO & $2.7 \pm 0.3$ & $0.2 \pm 0.1$ \\
Adrenochrome/BNAH & $30.9 \pm 2.5^{* * *}$ & $41.4 \pm 0.01^{* * *}$ \\
M-11 $(100 \mu \mathrm{M})+$ Adrenochrome/BNAH & $32.3 \pm 4.8$ & $35.7 \pm 0.5^{\# \#}$ \\
S29434 $(25 \mu \mathrm{M})+$ Adrenochrome/BNAH & $32.5 \pm 2.2$ & $19.4 \pm 0.9^{\# \# \#}$ \\
$\mathrm{M}-11(100 \mu \mathrm{M})$ & $2.3 \pm 0.8$ & $0.5 \pm 0.07$ \\
S29434 $(25 \mu \mathrm{M})$ & $2.8 \pm 0.09$ & $0.6 \pm 0.03$ \\
\hline
\end{tabular}

HT-22 cells were treated with M-11 $(100 \mu \mathrm{M})$ or with S29434 $(25 \mu \mathrm{M})$ for 45 min followed by incubation with adrenochrome and BNAH for an additional $120 \mathrm{~min}$, after which cells were washed with PBS and incubated in DMEM, containing 5\% FBS for $24 \mathrm{~h}$. All experiments were performed in 9 replicates. Data shown as mean \pm SD (*** $p<0.001$ vs. $0.3 \%$ DMSO; \#\#\# $p<0.001$ compared with "Adrenochrome/BNAH" group; one-way ANOVA with Tukey's post-hoc).

\section{Discussion}

Data demonstrating NQO2 expression in HT-22 immortalized mouse hippocampal neuronal cells are consistent with those previously reported by Chomarat et al. on immunostaining and enzymatic activity studies, where HT-22 cells were used for cellular knock-down of NQO2 [82]. Expression and enzymatic activity of NQO2 revealed by various approaches, low basal level of NAD(P)H dehydrogenase [quinone] 1 (NQO1; QR1) 
homologous enzyme [83], ensure the adequacy of using HT-22 cells for modeling oxidative cellular damage in the presence of $\mathrm{NQO} 2$ substrate and co-substrate.

NQO2 crystallizes as a homodimer, and the reduction reaction catalysis is of a pingpong type $[36,84]$. NQO2 is significantly superior to NQO1 in the reduction of orthoquinone metabolic products of endogenous catecholamines (aminochrome, adrenochrome, dopachrome) $[37,44]$, which is associated with the specifics of hydrogen bond formation in the active site of the enzyme [36,85]. Unlike NQO1 [86], NQO2 does not recognize $\mathrm{NAD}(\mathrm{P}) \mathrm{H}$ and uses $\mathrm{N}$-alkyl nicotinamide derivatives (NMNH, NRH, BNAH) as hydrogen donors [36]. The given data determine the choice of adrenochrome and BNAH as substrates and co-substrates.

Published data indicate the contribution of NQO2 enzymatic activity to the generation of $\mathrm{O}_{2}{ }^{\bullet-}$ under conditions of increased generation of enzyme substrates $[43,44,87]$. In the nervous system, similar processes are distinctive to the NQO2-catalyzed reduction of orthoquinone derivatives of catecholamines, for example, aminochrome [32,42] (Figure 1). Since the rates of cyclization reactions of dopamine o-quinone and its subsequent oxidation significantly exceed the rate of aminochrome rearrangement, the latter can temporarily accumulate in the cytosol $[42,88]$ and, being a substrate of NQO2, contribute to the intensification of oxidative stress $[26,27,32,42]$ (Figure 1). Similar patterns have been demonstrated for norepinephrine [19] and adrenaline [89]. In addition, the contribution of NQO2 to cellular damage may also be associated with the oxidation of the co-substrate $\mathrm{NRH}$ to $\mathrm{NR}+$ with subsequent formation of 4-pyridone-3-carboxamide riboside in the presence of $\mathrm{O}_{2}{ }^{\bullet-}$, which activates cell autophagy in vitro [90]. Therefore, to study ROS production in the presence of adrenochrome and $\mathrm{BNAH}$, the DNA-binding CellROX Green Reagent [91] and CM- $\mathrm{H}_{2}$ DCFDA [92] dyes were chosen. CellROX Green Reagent is oxidized by $\mathrm{O}_{2}{ }^{\bullet-}$ and hydroxyl radical $\left(\mathrm{OH}^{\bullet}\right)$, unlike $\mathrm{H}_{2} \mathrm{O}_{2}$, and is used in ROS generation models with menadione (vitamin K3)-exogenous para-quinone with $\mathrm{NQO} 2$ substrate properties [93,94]. $\mathrm{CM}-\mathrm{H}_{2}$ DCFDA was used as a general oxidative stress indicator [92].

Our experiments in HT-22 cells showed an increase in CellROX Green Reagent and CM$\mathrm{H}_{2}$ DCFDA fluorescence in the presence of the endogenous NQO2 substrate adrenochrome $(125 \mu \mathrm{M})$ and BNAH $(100 \mu \mathrm{M})$. The data obtained suggest an increase in $\mathrm{O}_{2}{ }^{\bullet-}$ production which is consistent with the results of in vitro studies in other cell models. Thus, K562 cell incubation with adrenochrome $(100 \mu \mathrm{M})$ and BNAH $(100 \mu \mathrm{M})$ caused an increase in ROS production evaluated through the electron paramagnetic resonance (EPR) spectra intensities [43]. In addition, an increase in ROS production in the presence of the same concentrations of adrenochrome and BNAH was detected on CHO, SHSY-5Y and C3H cell lines, overexpressing $\mathrm{NQO} 2$ in comparison with basal expression $[43,44]$.

The ability of the NQO2 inhibitors M-11 $(100 \mu \mathrm{M})$ and S29434 $(25 \mu \mathrm{M})$ to prevent an increase in ROS generation caused by incubation of HT-22 cells with adrenochrome and BNAH is consistent with previously demonstrated action of S29434 in vitro [51,81]. It was found in various cell models using the EPR method that pre-incubation with S29434 (20 $\mu \mathrm{M})$ for $30 \mathrm{~min}$ prevented an increase in ROS production caused by adrenochrome $(100 \mu \mathrm{M})$ and BNAH $(100 \mu \mathrm{M})$ [43]. Other NQO2 inhibitors (quercetin, resveratrol, imatinib) as well as a specific miRNA silencing of NQO2 had a similar effect on ROS production [49].

In our in vitro study, the ability of endogenous substrate $\mathrm{NQO} 2$ adrenochrome to enhance nuclear DNA damage of cells with confirmed expression of NQO2 in the presence of co-substrate BNAH was established for the first time using the comet assay method. An increase in the percentage of DNA in the comet tail and atypical comets upon incubation of HT-22 cells with adrenochrome $(50-200 \mu \mathrm{M})$ is consistent with the ability of its precursor adrenaline (5-300 $\mu \mathrm{M})$ to increase the total comet score [95] in human lymphocytes measured by the comet assay after $1 \mathrm{~h}, 2 \mathrm{~h}$ and $4 \mathrm{~h}$ of treatment [96]. The authors of the study associate the damaging effects of adrenaline with the formation of oxidative products of adrenaline. This assumption is consistent with the possibility of complete oxidation of adrenaline $(10 \mu \mathrm{M})$ to adrenochrome within $120 \mathrm{~min}$ in a cell-free system and an increase in the formation of 8-oxodG in vitro in the presence of variable charge metals [97]. The 
contribution of NQO2 to DNA damage of human lymphocytes by quinone derivatives of adrenaline is also confirmed by an increase in the percentage of comet-tail DNA during incubation of cells with menadione under conditions of homologous enzyme NQO1 inhibition [98]. DNA damage of HT-22 cells, caused by the co-incubation of adrenochrome $(50-200 \mu \mathrm{M})$ and BNAH for up to $120 \mathrm{~min}$, revealed in the current research, is consistent with the ability of adrenochrome to disrupt DNA synthesis and transcription $[97,99]$.

To quantitatively study the effect of NQO2 inhibitors on the DNA damage of HT-22 cells, a concentration of $125 \mu \mathrm{M}$ of adrenochrome was chosen, under which, when incubated with BNAH, adrenochrome causes ROS production and an increase in the percentage of comet-tail DNA in the absence of atypical comets, which are traditionally analyzed separately $[80,95]$. In control experiments without BNAH, adrenochrome $(125 \mu \mathrm{M})$ did not enhance DNA damage, which is consistent with a close to basal level of ROS production upon incubation of K562 cells with adrenochrome at a $100 \mu \mathrm{M}$ concentration [43].

In our study, the effect of $30 \mathrm{~min}$ pre-incubation M-11 at concentrations of 50 and $100 \mu \mathrm{M}$ was more pronounced compared to S29434 at the same concentrations. At the same time, S29434 was already effective at a concentration of $10 \mu \mathrm{M}$. At 45 min pre-incubation the effect of both compounds at concentrations of 25-100 $\mu \mathrm{M}$ was equal. The protective effect of the M-11 compound (25-100 $\mu \mathrm{M})$ on HT-22 cells DNA when incubated with endogenous substrate of the enzyme adrenochrome and co-substrate $\mathrm{BNAH}$ is consistent with our previously published results [73]. Under conditions of NQO1 inhibition, preincubation (30 $\mathrm{min}$ ) of bone marrow cells of ICR mice with the M-11 compound (30 or $50 \mu \mathrm{M})$ attenuated menadione-induced DNA damage, more than halving the percentage of DNA in the comet tail [72,73]. It is important to note that the minimum effective concentrations of S29434 compound (10 and $25 \mu \mathrm{M})$ identified in this study by the comet assay cause almost complete inhibition of $\mathrm{NQO} 2$ in vitro [100]. Moreover, the protective effect of M-11 and S29434 is consistent with their ability to downregulate ROS production in the presence of adrenochrome and BNAH, shown in this work and in the study of Cassagnes et al. [43]. The increase in time of incubation or in concentration of adrenochrome leads to the formation of atypical comets, which reflects severe DNA damage [79,80]. NQO2 inhibitors M-11 and S29434 were able to reduce the number of atypical comets, possibly attenuating this type of ROS-induced DNA damage. Therefore, the action of both compounds on short- and long-term exposure of HT-22 cells to adrenochrome is similar. The lower effectiveness of M-11 compared to S29434 in ROS mitigation, comet assay at $30 \mathrm{~min}$ pre-incubation time and apoptosis assay can be explained by a higher affinity of S29434 towards NQO2 and a different lipophilicity of compounds [57,68].

To date, it has been proven that ROS overproduction and oxidative damage to macromolecules, including DNA, are implicated in the pathogenesis of neurodegenerative diseases [101,102]. Therefore, a protective effect of NQO2 inhibitors revealed when incubated with an endogenous substrate adrenochrome resulted in a decrease in both the percentage of DNA in the comet tail and the percentage of atypical comets. This can be considered as a component of the neuroprotective effect under enzyme-inhibition conditions. This assumption is consistent with the data obtained in the apoptosis assay $[103,104]$.

In vitro studies, carried out in the present work, are in agreement with the results of our in vivo studies. In the model of Parkinson's disease, we have shown neuroprotective effect of M-11 (7.5 mg/kg, i.p.) when the compound was administered over 14 days to ICR mice, starting on the day of 6-OHDA injection [74]. The neuroprotective effect of M-11 is consistent with the ability of the NQO2 inhibitor S29434 to prevent ROS production and cell death induced by paraquat in vitro and in vivo [100,105], as well as to exert a protective effect on dopaminergic neurons when incubated with the active metabolite of 1-methyl-4-phényl-1,2,3,6-tetrahydropyridine MPP+ [81]. The ability of NQO2 inhibitors to cause neuroprotection is in line with the improved learning abilities of $\mathrm{NqO}^{-/-}$mice in the Morris water maze task [106]. Clinical studies have shown increased expression of the NQO2 gene in patients with Alzheimer's [107] and Parkinson's [108] diseases. 
Thus, the present study using HT-22 hippocampal cell culture represents an experimental model for studying the contribution of NQO2 to the neuronal damage in vitro. NQO2 inhibitor M-11, a 2-mercaptobenzimidazole derivative, prevented ROS production and nuclear DNA damage, and decreased the percentage of late apoptotic cells. The protective effect of $\mathrm{NQO} 2$ inhibition suggests that this mechanism can be considered as a pharmacological target to ensure neuroprotection, and the M-11 compound is a convenient analytical tool and possible candidate for a new neuroprotective agent development.

\section{Materials and Methods}

\subsection{Chemicals}

M-11 compound (2-[2-(3-oxomorpholin-4-il)-ethylthio]-5-ethoxybenzimidazole hydrochloride) (Figure S4) was synthesized in FSBI "Zakusov Institute of Pharmacology" (Moscow, Russia) as described in [109], adrenochrome (3-hydroxy-1-methyl-2,3-dihydroindole-5,6-dione), bovine serum albumin (BSA), fetal bovine serum (FBS), menadione (2-methylnaphthalene1,4-dione), dicoumarol (4-hydroxy-3-[(4-hydroxy-2-oxochromen-3-yl)methyl]chromen-2-one), RPMI-1640, glycerin, L-glutamine, sodium deoxycholate, polyacrylamide gel (PAGE), EGTA, EDTA, EDTA-Na $, \mathrm{NaCl}_{2} \mathrm{NaOH}, \mathrm{PBS}$, PMSF, SDS, Tris-HCl, TBS-T, tert-butyl hydroperoxide (TBHP), propidium iodide (PI), 1X protease inhibitor cocktail (\#P8340), 1X phosphatase inhibitor cocktail 2 (\#P5726), 1X phosphatase inhibitor cocktail 3 (\#P0044) were purchased from Sigma-Aldrich (St-Louis, MO, USA); Triton X-100 and DMSO were purchased from Amresco (Solon, OH, USA); DMEM was purchased from HyClone (Marlborough, MA, USA); S29434 (N-(2-(2-methoxy-6H-dipyrido [2,3-a:3', 2'-e]pyrrolizin-11-yl)ethyl)furan-2-carboxamide) was purchased from MedChemExpress (Monmouth Junction, NJ, USA); BNAH (1-benzyl1,4-dihydronicotinamide) was purchased from USBiological (Salem, MA, USA); light melting agarose type 4 and high melting agarose type 1 were purchased from Panreac (Barcelona, Spain); SYBR-Green I dye was purchased from Invitrogen (Carlsbad, CA, USA); Pierce BCA Protein Assay Kit (\#23225), polyclonal rabbit anti-NQO2 antibodies (1:1000, PA5-96324), CellROX Green Reagent (\#C10444), CM- $\mathrm{H}_{2}$ DCFDA (\# C6827) and Annexin V-FITC Apoptosis Detection Kit (\#BMS500FI/100) were purchased from Thermo Fisher Scientific (Waltham, MS, USA); SignalFire Elite ECL Reagent, rabbit anti-a-tubulin antibodies (1:1000; \#2125), secondary antibody conjugated with HRP (anti-rabbit IgG, 1:12,000, \#7074) were purchased from Cell Signaling (Danvers, MA, USA).

\subsection{HT-22 Immortalized Mouse Hippocampal Neuronal Cell Culture}

The HT-22 cell line was a kind gift from Prof. F. Wiegant (Utrecht University, Netherlands) [110]. HT-22 cells were maintained in DMEM medium, 5\% FBS, $2 \mathrm{mM} \mathrm{L-glutamine}$ in $5 \% \mathrm{CO}_{2}$ and $95 \%$ air at $37^{\circ} \mathrm{C}$, and were passaged by trypsinization.

For Western blot analysis and comet assay, HT-22 cells were cultured in 6-well plates (Corning, NY, USA) $(1.8 \times 105$ cells/well $)$ in DMEM containing 5\% FBS for $72 \mathrm{~h}$. For flow cytometry detection of ROS production, HT-22 cells were cultured in 12-well plates (Corning, NY, USA) $(2 \times 105$ cells / well $)$ in DMEM, containing 5\% FBS for $24 \mathrm{~h}$.

\subsection{Incubation of HT-22 Cells with Substrate, Co-Substrate and Inhibitors of NQO2}

All NQO2 substrates, co-substrate and inhibitors were dissolved in appropriate solvents immediately prior to their addition to the culture medium. Stock solution of NQO2 substrate adrenochrome $(200 \mathrm{mM})$, co-substrate BNAH $(100 \mathrm{mM})$ and inhibitor S29434 $(10 \mathrm{mM})$ were prepared in DMSO, stock solution of another NQO2 inhibitor M-11 $(10 \mathrm{mM})$ was prepared in the growth medium. Serial dilutions of adrenochrome and M-11 were made in the growth medium and S29434 in DMSO. Serial dilutions of BNAH were made in DMSO for comet assay. Adrenochrome was used in final concentrations of 50, 100, 125, 150 and $200 \mu \mathrm{M}$. Final concentration of BNAH was $100 \mu \mathrm{M}$. HT-22 cells were exposed to adrenochrome and BNAH in combination or separately for 15 min for ROS measurements, 30, 60, 90 and $120 \mathrm{~min}$ for comet assay and $120 \mathrm{~min}$ for apoptosis assay. Inhibitors M-11 and S29434 at final concentrations of 1.0, 10, 25, 50 and $100 \mu \mathrm{M}$ were added to culture 
medium 30 or 45 min prior to the exposure of HT-22 cells to adrenochrome and BNAH. Final concentrations of DMSO were $2 \%$ for comet assay, $0.2 \%$ for ROS measurement and $0.3 \%$ for apoptosis assay. DMSO was used in all experimental groups except for intact cells.

\subsection{Protein Preparation and Western Blot Analysis}

Cells were lysed with RIPA buffer (10 mM Tris- $\mathrm{HCl}$ (pH 8.0), $1 \mathrm{mM}$ EDTA, $0.5 \mathrm{mM}$ EGTA, $1 \%$ Triton X-100, $0.1 \%$ sodium deoxycholate, $0.1 \%$ SDS, $0.14 \mathrm{mM} \mathrm{NaCl}, 1 \mathrm{X}$ protease inhibitor cocktail (\#P8340), $1 \times$ phosphatase inhibitor cocktail 2 and 3 (\#P5726, P0044), $1 \mathrm{mM}$ PMSF). Protein concentration was determined using Pierce BCA Protein Assay Kit. Lysate were loaded on SDS-PAGE and separated proteins were transferred onto nitrocellulose membranes (\#GE10600002, Sigma-Aldrich, St-Louis, MO, USA). The membranes were blocked in $5 \%$ non-fat milk or $5 \%$ BSA in TBS-T for $60 \mathrm{~min}$ at room temperature, incubated with the appropriate primary antibody $\left(+4{ }^{\circ} \mathrm{C}\right.$, overnight) and then with a secondary antibody conjugated with HRP (60 min at room temperature). Bands were visualized using SignalFire Plus ECL Reagent. Membranes were scanned using Amersham Imager 680 (GE HealthCare, Chicago, IL, USA) and quantified in Image Quant TL v.8.1 (GE HealthCare, Chicago, IL, USA). Alpha-tubulin was used as loading control.

\subsection{ROS Measurement}

For flow cytometry detection of general ROS production, HT-22 cells were pre-loaded with $5 \mu \mathrm{M}$ of $\mathrm{CM}-\mathrm{H}_{2}$ DCFDA as a general oxidative stress indicator in serum-free DMEM. After staining procedure $\left(30 \mathrm{~min}, 37^{\circ} \mathrm{C}, 5 \% \mathrm{CO}_{2}\right)$, loading media were replaced by DMEM, containing $5 \% \mathrm{FBS}$ for $\mathrm{CM}-\mathrm{H}_{2}$ DCFDA cleavage by intracellular esterases $\left(20 \mathrm{~min}, 37^{\circ} \mathrm{C}\right.$, $5 \% \mathrm{CO}_{2}$ ). Cells were exposed to M-11 and S29434 in final concentrations of 10, 25, 50 and $100 \mu \mathrm{M}$ for $45 \mathrm{~min}$ and then to adrenochrome and BNAH for $15 \mathrm{~min}$. As a positive control, $200 \mu \mathrm{M}$ of TBHP (30 min) was used. The samples were harvested, stained with PI $(25 \mu \mathrm{g} / \mathrm{mL} ; 5 \mathrm{~min})$ and analyzed by NovoCyte 2060 flow cytometer (Acea Biosciences Inc., San Diego, CA, USA), using $488 \mathrm{~nm}$ excitation and collecting fluorescence emission; a $530 / 30$ bandpass filter for $\mathrm{CM}-\mathrm{H}_{2}$ DCFDA and a $690 / 50 \mathrm{BP}$ filter for propidium iodide (PI) dead cell staining. Following application of standard fluorescence compensation technique, medians of fluorescence histogram (MFI) into $\mathrm{CM}-\mathrm{H}_{2} \mathrm{DCFDA}^{+} / \mathrm{PI}^{-}$cell populations were used for statistical analysis (15,000 events were collected in each probe gated as "live cells").

For flow cytometry detection of subcellular ROS production, cells were pre-stained with $5 \mu \mathrm{M}$ of CellROX Green Reagent according to the manufacturer's recommendations. After a staining procedure $\left(15 \mathrm{~min}, 37^{\circ} \mathrm{C}, 5 \% \mathrm{CO}_{2}\right)$ media were replaced by DMEM, containing 5\% FBS. Cells were exposed to adrenochrome and BNAH for 5 or $15 \mathrm{~min}$. As a positive control, $200 \mu \mathrm{M}$ of TBHP (30 min) was used. The samples were harvested, stained with PI ( $25 \mu \mathrm{g} / \mathrm{mL} ; 5 \mathrm{~min})$ and analyzed by NovoCyte 2060 flow cytometer (Acea Biosciences Inc., San Diego, CA, USA), using $488 \mathrm{~nm}$ excitation and collecting fluorescence emission in median fluorescence intensity (MFI); a 530/30 bandpass filter for CellROX Green Reagent and a 690/50 BP filter for PI dead cell staining. Following application of standard fluorescence compensation technique, medians of fluorescence histogram (MFI) into CellROX Green ${ }^{+} / \mathrm{PI}^{-}$cell populations were used for statistical analysis $(15,000$ events were collected in each probes gated as "live cells").

\subsection{Apoptosis Assay}

For the detection of apoptotic stages, HT-22 cells were treated with M-11 $(100 \mu \mathrm{M})$, S29434 $(25 \mu \mathrm{M})$ for $45 \mathrm{~min}$ and then with adrenochrome and BNAH for an additional 120 min. After the treatment cells were washed with PBS and incubated in DMEM, containing $5 \%$ FBS for $24 \mathrm{~h}$, cells were harvested and stained with Annexin V-FITC Apoptosis Detection Kit according to the manufacturer's recommendations. The samples were analyzed by NovoCyte 2060 flow cytometer (Acea Biosciences Inc., San Diego, CA, USA), using 488 nm excitation and collecting fluorescence emission: a 530/30 bandpass filter for Annexin V-FITC and a 690/50 BP filter for PI dead cell staining. Following application of standard 
fluorescence compensation technique, cell percentages of Annexin V/PI dual parameter dot plot were used for statistical analysis (10,000 events were collected in each probe).

\subsection{Single-Cell Gel Electrophoresis Assay (Alkaline Comet Assay)}

All the procedures were conducted under dim light to prevent the occurrence of additional DNA damage. After the incubation with adrenochrome and after BNAH cells were washed in $1 \mathrm{~mL}$ of PBS, $500 \mu \mathrm{L}$ of PBS was added into the well and cells were scraped off the plate, transferred into an Eppendorf tube and suspended. After that, $35 \mu \mathrm{L}$ of cell suspension was intensely mixed with $175 \mu \mathrm{L}$ of $0.9 \%$ light melting agarose solution. The same amount of obtained mixture was dropped on slides pre-coated with $1 \%$ of high melting agarose. The slides were covered with coverslips and placed on ice for $5 \mathrm{~min}$. After gel solidification coverslips were gently removed and slides were placed into a Schifferdecker-type glass cuvette filled with ice cold lysis solution $(10 \mathrm{mM}$ Tris$\mathrm{HCl}, 2,5 \mathrm{M} \mathrm{NaCl}, 100 \mathrm{mM}$ EDTA-Na $2,1 \%$ Triton X-100, 10\% DMSO, $\mathrm{pH} 10,4{ }^{\circ} \mathrm{C}$ ) and incubated at $4{ }^{\circ} \mathrm{C}$ for at least $1 \mathrm{~h}$. After the lysis step, the slides were washed in deionized water and placed into a cuvette filled with alkaline buffer $(300 \mathrm{mM} \mathrm{NaOH}, 1 \mathrm{mM}$ EDTA$\mathrm{Na}_{2}, \mathrm{pH}>13,4{ }^{\circ} \mathrm{C}$ ) for $20 \mathrm{~min}$. After the denaturation step, slides were transferred to the electrophoresis chamber (BioRad, Hercules, CA, USA), filled with $2.2 \mathrm{~L}$ of the same solution. Electrophoresis was performed for $20 \mathrm{~min}$ at electric field strength of $1.0 \mathrm{~V} / \mathrm{cm}$; the applied voltage was $32 \mathrm{~V}$ and the current was $400 \mathrm{~mA}$. After electrophoresis, the slides were washed in $1 \times \mathrm{PBS}$, fixed in 70\% ethanol at room temperature. Then, drying slides were stained with SYBR Green I (1:10,000 in TE buffer/glycerin (1:1 v/v), pH 8.5) for $30 \mathrm{~min}$ in the dark. Analysis was performed on a Mikmed-2 12T epifluorescence microscope ("LOMO", St. Petersburg, Russia) combined with a high-resolution digital camera (VEC-335, St. Petersburg, Russia), at $100 \times$ magnification. The images of comets were analyzed using CASP v.1.2.3 software (www.casplab.com). The DNA damage was evaluated by the percentage of DNA in the tail of the comet (\% tDNA). Spontaneous DNA damage was measured in intact cells incubated in cultural medium only. Control groups included cells incubated with 2\% DMSO, adrenochrome or BNAH. Each experimental group was characterized by mean and standard deviation of medians of \% tDNA obtained as a result of analysis of at least 100 non-atypical comets per slide. The percentage of atypical comets was counted as ratio of non-overlapping comets with barely visible or invisible nucleoid head and large, broad tail to the total amount of non-overlapping comets. For examples of comets used in the analysis, see Figure S2. All experiments were performed in six repetitions.

\subsection{Experimental Animals}

The study was performed in male ICR (CD-1) mice (25-30 g, $n=5)$ obtained from Pushchino Breeding Center (Branch of the Institute of Bioorganic Chemistry, Russian Academy of Sciences). Animals were housed under standard vivarium conditions (20$22{ }^{\circ} \mathrm{C}, 30-70 \%$ humidity, $12 \mathrm{~h}$ light/dark cycle) in plastic cages with sawdust bedding and 5 animals per cage.

\subsection{Ethical Approval}

All experimental procedures were approved by the bioethics committee of the FSBI "Zakusov Institute of Pharmacology", protocol \#08 of 30 September 2021. All applicable national [111] and international [112] guidelines for care and use of experimental animals were followed.

\subsection{ICR Mice Bone Marrow Cells}

Mice were sacrificed by cervical dislocation. Epiphysis of femurs were cut off and bone marrow cells were flushed with $3 \mathrm{~mL}$ of RPMI-1640 medium containing 10\% FBS per bone. The sample from each animal was divided in $300 \mu \mathrm{L}$ aliquots and pre-incubated at $37^{\circ} \mathrm{C}$ in the presence or absence of $10 \mu \mathrm{M}$ dicoumarol with DMSO or M-11 in final 
concentrations of 5, 10, 15, 30 and $50 \mu \mathrm{M}$ for $30 \mathrm{~min}$. After pre-incubation suspension of bone marrow cells was incubated with menadione at a final concentration of $25 \mu \mathrm{M}$ for $60 \mathrm{~min}$ at $37^{\circ} \mathrm{C}$. After exposition to menadione alkaline comet assay was conducted as described in Section 4.6 with slight modifications, i.e., after the washing procedure, bone marrow cells were resuspended in $300 \mu \mathrm{L}$ of PBS.

Stock solutions of M-11, dicoumarol and menadione were prepared immediately prior to their addition to incubation medium. Stock solution of M-11 was prepared and diluted in RPMI. Solutions of dicoumarol and menadione were prepared in DMSO. Final concentration of DMSO did not exceed $2 \%$. All experiments were performed in five repetitions.

\subsection{Statistical Analysis}

To evaluate the experimental data distribution, D'Agostino-Pearson and Shapiro-Wilk tests were used. Statistical significance was calculated using one- or two-way ANOVA with Tukey's post-hoc test or Kruskal-Wallis test with Dunn's post-hoc test. Data are presented as the mean and standard deviation (mean \pm S.D.) or median with minimum and maximum (Mdn (min-max)). A value of $p<0.05$ was considered to be statistically significant. Statistical analysis and visualization were performed using GraphPad Prism software version 8.0.1 for Windows (GraphPad, La Jolla, CA, USA, www.graphpad.com).

Supplementary Materials: The following are available online at https:/ /www.mdpi.com/article/10 $.3390 /$ ijms222313061/s1.

Author Contributions: Conceptualization, M.V.V., Y.V.V. and S.B.S.; methodology, M.V.V., T.A.A., L.F.Z., Y.V.V., I.A.K. and S.B.S.; validation, M.V.V., I.O.L., L.F.Z. and I.A.K.; formal analysis, M.V.V., L.F.Z. and I.A.K.; investigation, E.R.V., I.O.L., L.F.Z. and I.A.K.; resources, T.A.A.; writing-original draft preparation, M.V.V., E.R.V. and Y.V.V.; writing-review and editing, M.V.V., E.R.V., T.A.A., L.F.Z., Y.V.V., I.A.K. and S.B.S.; visualization, M.V.V., E.R.V., L.F.Z. and I.A.K.; supervision, S.B.S.; project administration, M.V.V., T.A.A. and Y.V.V. All authors have read and agreed to the published version of the manuscript.

Funding: This research was funded by government contracts from the Ministry of Science and Higher Education of the Russian Federation (Project 0521-2019-0002).

Institutional Review Board Statement: The study was conducted according to the guidelines of the Declaration of Helsinki, and approved by the Institutional Ethics Committee of Federal State Budgetary Institution "Research Zakusov Institute of Pharmacology", Moscow, Russia (protocol \#08 of 30.09.2021).

Informed Consent Statement: Not applicable.

Data Availability Statement: All data are presented within the manuscript and Supplementary Materials or are available on request from the corresponding authors.

Acknowledgments: Authors would like to express their sincere gratitude to Aliy K. Zhanataev and Iosif B. Tsorin for their methodological consultations.

Conflicts of Interest: The authors declare no conflict of interest.

\section{Abbreviations}

6-OHDA 6-Hydroxydopamine: 5-(2-aminoethyl)benzene-1:2:4-triol

Afobazole 5-Ethoxy-2-[2-(morpholino)-ethylthio]benzimidazole dihydrochloride

BNAH 1-Benzyl-1,4-dihydronicotinamide

BSA Bovine serum albumin

C3H cells Murine embryo fibroblast cells

CHO cells Chinese hamster ovary cells

CM- $\mathrm{H}_{2}$ DCFDA acetic 2-[3,6-bis(acetyloxy)-2,7-dichloro-9H-xanthen-9-yl]-4-(chloromethyl)

benzoic anhydride 


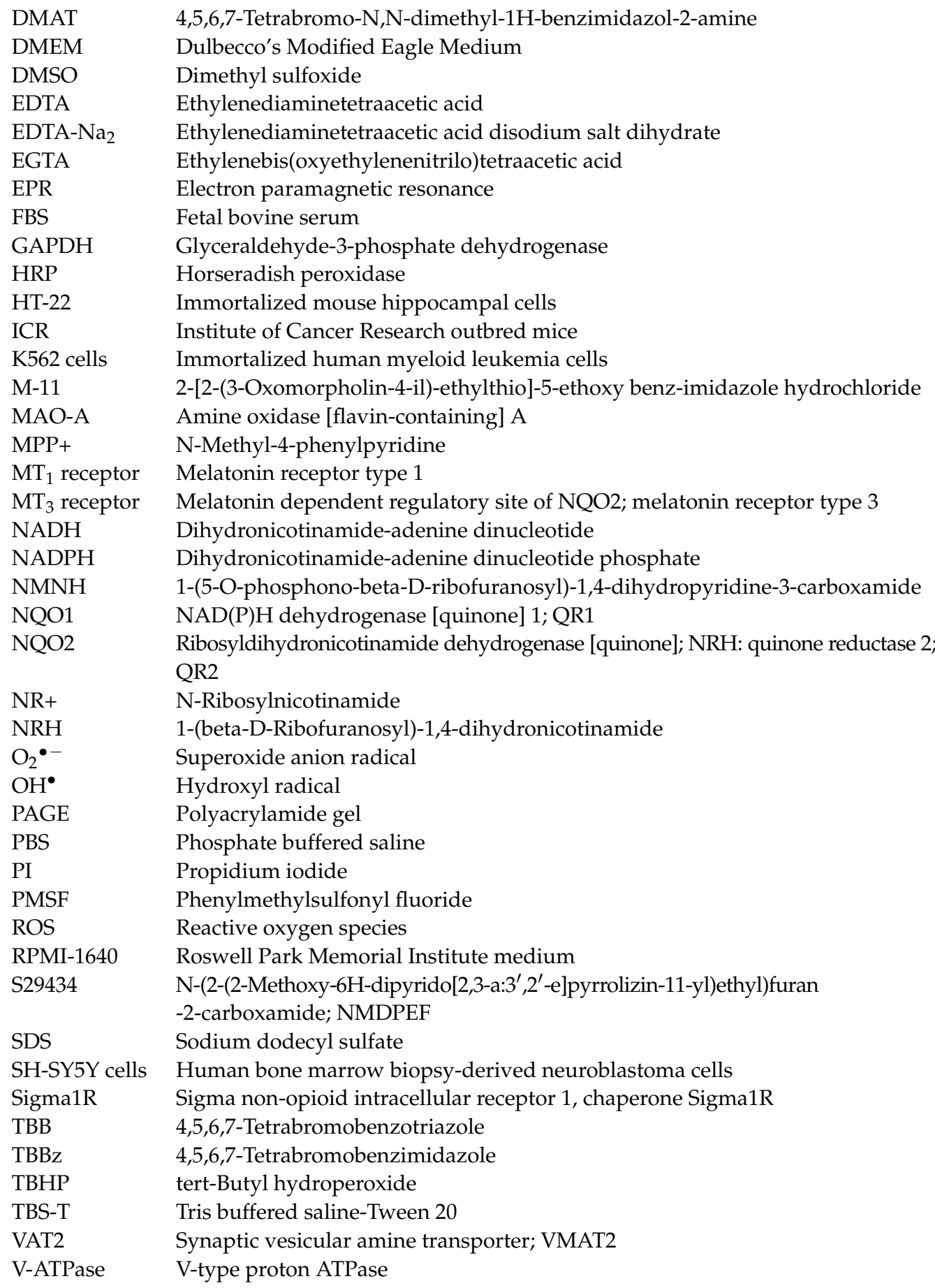

\section{Appendix A}

To study the influence of M-11 on NQO1, we utilized a pharmacological approach based on the comparison of $\mathrm{M}-11$ and dicoumarol effects on oxidative damage of nuclear DNA caused by NQO1 and NQO2 substrate menadione. In the used concentration of 10 $\mu \mathrm{M}$ dicoumarol totally inhibits NQO1, while reducing NQO2 activity for only $20 \%$ [52]. On bone marrow cells of ICR mice, we have reproduced an increase of DNA damage in the presence of dicoumarol ( $\mathrm{F}=31.57, p<0.001$; Figure A1) [72], which is consistent with Woods et al. [98] and provides evidence of the protective role of NQO1 [113]. We established a link between increased nuclear DNA damage and NQO2 activity earlier, using M-11 [72]. Figure A1 indicates that NQO2 inhibitor M-11 in 5-50 $\mu \mathrm{M}$ range does not cause the enhancement of DNA damage characteristic for NQO1 inhibition in this 
experimental model. The protective effect of $\mathrm{M}-11(\mathrm{~F}=46.83, p<0.001)$ in concentrations of 30 and $50 \mu \mathrm{M}$ manifested only under conditions of NQO1 inhibition by dicoumarol (interaction: $\mathrm{F}=8.28, p<0.001$ ), which is consistent with the protective effect of M-11, starting from a $25 \mu \mathrm{M}$ concentration, described in the current study. These data suggest the absence of any impact of M-11 in the used concentration range on NQO1 activity.

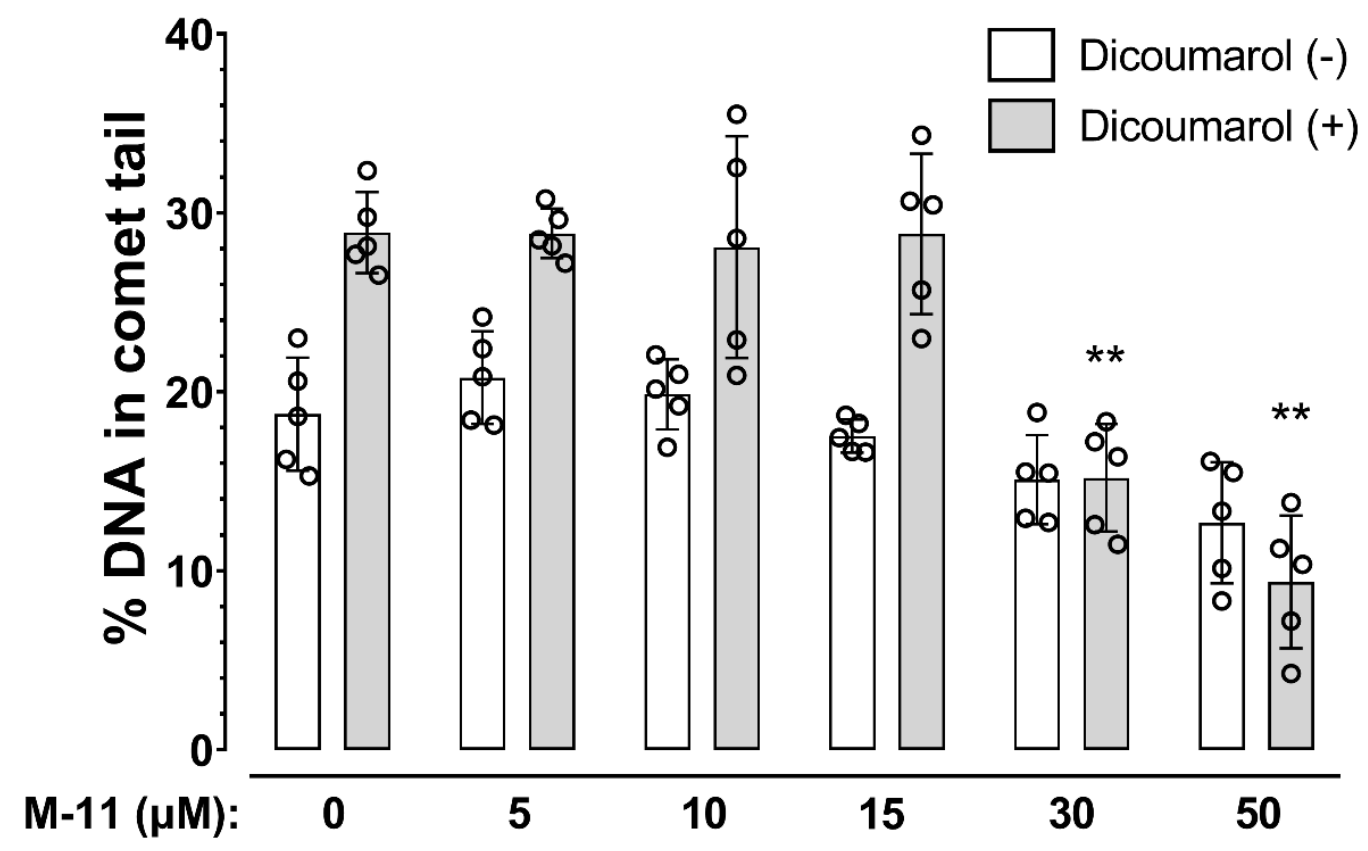

Figure A1. The influence of M-11 on nuclear DNA damage of ICR mice bone marrow cell suspension caused by menadione. Suspension of bone marrow cells of ICR mice was incubated with M-11 (5-50 $\mu \mathrm{M})$ in presence or absence of dicoumarol $(10 \mu \mathrm{M})$ for $30 \mathrm{~min}$. After pre-incubation, cells were incubated with menadione $(25 \mu \mathrm{M})$ for $60 \mathrm{~min}$. Data are presented as mean \pm S.D. Two-way ANOVA with Tukey's post-hoc was used: ${ }^{* *} p<0.001$ vs. pre-incubation without M-11.

\section{References}

1. Erkkinen, M.G.; Kim, M.O.; Geschwind, M.D. Clinical Neurology and Epidemiology of the Major Neurodegenerative Diseases. Cold Spring Harb. Perspect. Biol. 2018, 10, a033118. [CrossRef]

2. Gan, L.; Cookson, M.R.; Petrucelli, L.; La Spada, A.R. Converging pathways in neurodegeneration, from genetics to mechanisms. Nat. Neurosci. 2018, 21, 1300-1309. [CrossRef] [PubMed]

3. Van Bulck, M.; Sierra-Magro, A.; Alarcon-Gil, J.; Perez-Castillo, A.; Morales-Garcia, J.A. Novel Approaches for the Treatment of Alzheimer's and Parkinson's Disease. Int. J. Mol. Sci. 2019, 20, 719. [CrossRef]

4. Ruz, C.; Alcantud, J.L.; Vives Montero, F.; Duran, R.; Bandres-Ciga, S. Proteotoxicity and Neurodegenerative Diseases. Int. J. Mol. Sci. 2020, 21, 5646. [CrossRef]

5. Fu, H.; Hardy, J.; Duff, K.E. Selective vulnerability in neurodegenerative diseases. Nat. Neurosci. 2018, 21, 1350-1358. [CrossRef] [PubMed]

6. Cioffi, F.; Adam, R.H.I.; Broersen, K. Molecular Mechanisms and Genetics of Oxidative Stress in Alzheimer's Disease. J. Alzheimers Dis. 2019, 72, 981-1017. [CrossRef]

7. Puspita, L.; Chung, S.Y.; Shim, J.W. Oxidative stress and cellular pathologies in Parkinson's disease. Mol. Brain $2017,10,53$. [CrossRef] [PubMed]

8. Kumar, A.; Ratan, R.R. Oxidative Stress and Huntington's Disease: The Good, The Bad, and The Ugly. J. Huntingt. Dis. 2016, 5, 217-237. [CrossRef]

9. Obrador, E.; Salvador, R.; Lopez-Blanch, R.; Jihad-Jebbar, A.; Valles, S.L.; Estrela, J.M. Oxidative Stress, Neuroinflammation and Mitochondria in the Pathophysiology of Amyotrophic Lateral Sclerosis. Antioxidants 2020, 9, 901. [CrossRef] [PubMed]

10. Nimse, S.B.; Pal, D. Free radicals, natural antioxidants, and their reaction mechanisms. RSC Adv. 2015, 5, 27986-28006. [CrossRef]

11. Halliwell, B.; Gutteridge, J.M.C. Free Radicals in Biology and Medicine, 5th ed.; Oxford University Press: Oxford, UK, $2015 ;$ p. 905.

12. Laher, I. Back Matter. In Systems Biology of Free Radicals and Antioxidants; Springer: Berlin/Heidelberg, Germany, $2014 ;$ p. 4178.

13. Amato, A.; Terzo, S.; Mule, F. Natural Compounds as Beneficial Antioxidant Agents in Neurodegenerative Disorders: A Focus on Alzheimer's Disease. Antioxidants 2019, 8, 608. [CrossRef] 
14. Sharma, S.; Ebadi, M. Antioxidants as Potential Therapeutics in Neurodegeneration. In Systems Biology of Free Radicals and Antioxidants; Laher, I., Ed.; Springer: Berlin/Heidelberg, Germany, 2014; pp. 2191-2273. [CrossRef]

15. Charvin, D.; Medori, R.; Hauser, R.A.; Rascol, O. Therapeutic strategies for Parkinson disease: Beyond dopaminergic drugs. Nat. Rev. Drug Discov. 2018, 17, 804-822. [CrossRef] [PubMed]

16. Stower, H. Searching for Alzheimer's disease therapies. Nat. Med. 2018, 24, 894-897. [CrossRef]

17. Monzani, E.; Nicolis, S.; Dell'Acqua, S.; Capucciati, A.; Bacchella, C.; Zucca, F.A.; Mosharov, E.V.; Sulzer, D.; Zecca, L.; Casella, L. Dopamine, Oxidative Stress and Protein-Quinone Modifications in Parkinson's and Other Neurodegenerative Diseases. Angezw. Chem. 2019, 58, 6512-6527. [CrossRef]

18. Chen, L.; Ding, Y.; Cagniard, B.; Van Laar, A.D.; Mortimer, A.; Chi, W.; Hastings, T.G.; Kang, U.J.; Zhuang, X. Unregulated cytosolic dopamine causes neurodegeneration associated with oxidative stress in mice. J. Neurosci. 2008, 28, 425-433. [CrossRef]

19. Manini, P.; Panzella, L.; Napolitano, A.; d'Ischia, M. Oxidation Chemistry of Norepinephrine: Partitioning of the O-Quinone between Competing Cyclization and Chain Breakdown Pathways and Their Roles in Melanin Formation. Chem. Res. Toxicol. 2007, 20, 1549-1555. [CrossRef]

20. Masato, A.; Plotegher, N.; Boassa, D.; Bubacco, L. Impaired dopamine metabolism in Parkinson's disease pathogenesis. Mol. Neurodegener. 2019, 14, 35. [CrossRef] [PubMed]

21. Simic, G.; Babic Leko, M.; Wray, S.; Harrington, C.R.; Delalle, I.; Jovanov-Milosevic, N.; Bazadona, D.; Buee, L.; de Silva, R.; Di Giovanni, G.; et al. Monoaminergic neuropathology in Alzheimer's disease. Prog. Neurobiol. 2017, 151, 101-138. [CrossRef]

22. Cepeda, C.; Murphy, K.P.; Parent, M.; Levine, M.S. The role of dopamine in Huntington's disease. Prog. Brain Res. 2014, 211, 235-254. [CrossRef] [PubMed]

23. Chen, J.Y.; Wang, E.A.; Cepeda, C.; Levine, M.S. Dopamine imbalance in Huntington's disease: A mechanism for the lack of behavioral flexibility. Front. Neurosci. 2013, 7, 114. [CrossRef]

24. de Diego-Balaguer, R.; Schramm, C.; Rebeix, I.; Dupoux, E.; Durr, A.; Brice, A.; Charles, P.; Cleret de Langavant, L.; Youssov, K.; Verny, C.; et al. COMT Val158Met Polymorphism Modulates Huntington's Disease Progression. PLoS ONE 2016, 11, e0161106. [CrossRef]

25. Guillot, T.S.; Miller, G.W. Protective actions of the vesicular monoamine transporter 2 (VMAT2) in monoaminergic neurons. Mol. Neurobiol. 2009, 39, 149-170. [CrossRef] [PubMed]

26. Segura-Aguilar, J.; Paris, I. Mechanisms of Dopamine Oxidation and Parkinson's Disease. In Handbook of Neurotoxicity; Kostrzewa, R.M., Ed.; Springer: New York, NY, USA, 2014; pp. 865-883. [CrossRef]

27. Umek, N.; Gersak, B.; Vintar, N.; Sostaric, M.; Mavri, J. Dopamine Autoxidation Is Controlled by Acidic pH. Front. Mol. Neurosci. 2018, 11, 467. [CrossRef]

28. Tossounian, M.A.; Zhang, B.; Gout, I. The Writers, Readers, and Erasers in Redox Regulation of GAPDH. Antioxidants 2020, 9 , 1288. [CrossRef] [PubMed]

29. Bucher, M.L.; Barrett, C.W.; Moon, C.J.; Mortimer, A.D.; Burton, E.A.; Greenamyre, J.T.; Hastings, T.G. Acquired dysregulation of dopamine homeostasis reproduces features of Parkinson's disease. NPJ Parkinson Dis. 2020, 6, 34. [CrossRef]

30. Eiden, L.E.; Weihe, E. VMAT2: A dynamic regulator of brain monoaminergic neuronal function interacting with drugs of abuse. Ann. N. Y. Acad. Sci. 2011, 1216, 86-98. [CrossRef] [PubMed]

31. Mosharov, E.V. Regulation of DA Homeostasis and Role of VMAT2 in DA-Induced Neurodegeneration. In Handbook of Neurotoxicity; Kostrzewa, R.M., Ed.; Springer: New York, NY, USA, 2014; pp. 973-993. [CrossRef]

32. Herrera, A.; Munoz, P.; Steinbusch, H.W.M.; Segura-Aguilar, J. Are Dopamine Oxidation Metabolites Involved in the Loss of Dopaminergic Neurons in the Nigrostriatal System in Parkinson's Disease? ACS Chem. Neurosci. 2017, 8, 702-711. [CrossRef]

33. Wakamatsu, K.; Nakao, K.; Tanaka, H.; Kitahori, Y.; Tanaka, Y.; Ojika, M.; Ito, S. The Oxidative Pathway to Dopamine-Protein Conjugates and Their Pro-Oxidant Activities: Implications for the Neurodegeneration of Parkinson's Disease. Int. J. Mol. Sci. 2019, 20, 2575. [CrossRef] [PubMed]

34. Cavalieri, E.L.; Li, K.M.; Balu, N.; Saeed, M.; Devanesan, P.; Higginbotham, S.; Zhao, J.; Gross, M.L.; Rogan, E.G. Catechol ortho-quinones: The electrophilic compounds that form depurinating DNA adducts and could initiate cancer and other diseases. Carcinogenesis 2002, 23, 1071-1077. [CrossRef]

35. Zahid, M.; Saeed, M.; Yang, L.; Beseler, C.; Rogan, E.; Cavalieri, E.L. Formation of dopamine quinone-DNA adducts and their potential role in the etiology of Parkinson's disease. IUBMB Life 2011, 63, 1087-1093. [CrossRef]

36. Janda, E.; Nepveu, F.; Calamini, B.; Ferry, G.; Boutin, J.A. Molecular pharmacology of NRH:quinone oxidoreductase 2: A detoxifying enzyme acting as an undercover toxifying enzyme. Mol. Pharmacol. 2020, 98, 620-633. [CrossRef] [PubMed]

37. Fu, Y.; Buryanovskyy, L.; Zhang, Z. Quinone reductase 2 is a catechol quinone reductase. J. Biol. Chem. 2008, 283, 23829-23835. [CrossRef] [PubMed]

38. Bindoli, A.; Scutari, G.; Rigobello, M.P. The role of adrenochrome in stimulating the oxidation of catecholamines. Neurotox. Res. 1999, 1, 71-80. [CrossRef] [PubMed]

39. Bolton, J.L.; Dunlap, T. Formation and Biological Targets of Quinones: Cytotoxic versus Cytoprotective Effects. Chem. Res. Toxicol. 2017, 30, 13-37. [CrossRef]

40. Song, Y.; Buettner, G.R. Thermodynamic and kinetic considerations for the reaction of semiquinone radicals to form superoxide and hydrogen peroxide. Free Radic. Biol. Med. 2010, 49, 919-962. [CrossRef] [PubMed] 
41. Monks, T.J.; Hanzlik, R.P.; Cohen, G.M.; Ross, D.; Graham, D.G. Quinone chemistry and toxicity. Toxicol. Appl. Pharmacol. 1992, 112, 2-16. [CrossRef]

42. Segura-Aguilar, J.; Paris, I.; Munoz, P.; Ferrari, E.; Zecca, L.; Zucca, F.A. Protective and toxic roles of dopamine in Parkinson's disease. J. Neurochem. 2014, 129, 898-915. [CrossRef]

43. Cassagnes, L.E.; Chhour, M.; Perio, P.; Sudor, J.; Gayon, R.; Ferry, G.; Boutin, J.A.; Nepveu, F.; Reybier, K. Oxidative stress and neurodegeneration: The possible contribution of quinone reductase 2. Free Radic. Biol. Med. 2018, 120, 56-61. [CrossRef] [PubMed]

44. Cassagnes, L.E.; Perio, P.; Ferry, G.; Moulharat, N.; Antoine, M.; Gayon, R.; Boutin, J.A.; Nepveu, F.; Reybier, K. In cellulo monitoring of quinone reductase activity and reactive oxygen species production during the redox cycling of 1,2 and 1,4 quinones Free Radic. Biol. Med. 2015, 89, 126-134. [CrossRef] [PubMed]

45. Ruszkiewicz, J.; Albrecht, J. Changes in the mitochondrial antioxidant systems in neurodegenerative diseases and acute brain disorders. Neurochem. Int. 2015, 88, 66-72. [CrossRef]

46. Niedzielska, E.; Smaga, I.; Gawlik, M.; Moniczewski, A.; Stankowicz, P.; Pera, J.; Filip, M. Oxidative Stress in Neurodegenerative Diseases. Mol. Neurobiol. 2016, 53, 4094-4125. [CrossRef]

47. Bjorklund, G.; Peana, M.; Maes, M.; Dadar, M.; Severin, B. The glutathione system in Parkinson's disease and its progression. Neurosci. Biobehav. Rev. 2021, 120, 470-478. [CrossRef] [PubMed]

48. Mischley, L.K.; Standish, L.J.; Weiss, N.S.; Padowski, J.M.; Kavanagh, T.J.; White, C.C.; Rosenfeld, M.E. Glutathione as a Biomarker in Parkinson's Disease: Associations with Aging and Disease Severity. Oxidative Med. Cell. Longev. 2016, 2016, 9409363. [CrossRef] [PubMed]

49. Miettinen, T.P.; Bjorklund, M. NQO2 is a reactive oxygen species generating off-target for acetaminophen. Mol. Pharm. 2014, 11, 4395-4404. [CrossRef]

50. Brain Tissue Expression of NQO2. Available online: https://www.proteinatlas.org/ENSG00000124588-NQO2/tissue (accessed on 1 December 2021).

51. Chen, D.; Li, X.; Liu, X.; Liu, X.; Jiang, X.; Du, J.; Wang, Q.; Liang, Y.; Ma, W. NQO2 inhibition relieves reactive oxygen species effects on mouse oocyte meiotic maturation and embryo development. Biol. Reprod. 2017, 97, 598-611. [CrossRef] [PubMed]

52. Zhao, Q.; Yang, X.L.; Holtzclaw, W.D.; Talalay, P. Unexpected genetic and structural relationships of a long-forgotten flavoenzyme to NAD(P)H:quinone reductase (DT-diaphorase). Proc. Natl. Acad. Sci. USA 1997, 94, 1669-1674. [CrossRef]

53. Foster, C.E.; Bianchet, M.A.; Talalay, P.; Zhao, Q.; Amzel, L.M. Crystal structure of human quinone reductase type 2, a metalloflavoprotein. Biochemistry 1999, 38, 9881-9886. [CrossRef] [PubMed]

54. Molinari, E.J.; North, P.C.; Dubocovich, M.L. 2-[125I]iodo-5-methoxycarbonylamino-N-acetyltryptamine: A selective radioligand for the characterization of melatonin ML2 binding sites. Eur. J. Pharmacol. 1996, 301, 159-168. [CrossRef]

55. Nosjean, O.; Ferro, M.; Coge, F.; Beauverger, P.; Henlin, J.M.; Lefoulon, F.; Fauchere, J.L.; Delagrange, P.; Canet, E.; Boutin, J.A. Identification of the melatonin-binding site MT3 as the quinone reductase 2. J. Biol. Chem. 2000, 275, 31311-31317. [CrossRef]

56. Boutin, J.A.; Ferry, G. Is There Sufficient Evidence that the Melatonin Binding Site MT3 Is Quinone Reductase 2? J. Pharmacol. Exp. Ther. 2019, 368, 59-65. [CrossRef]

57. Ferry, G.; Hecht, S.; Berger, S.; Moulharat, N.; Coge, F.; Guillaumet, G.; Leclerc, V.; Yous, S.; Delagrange, P.; Boutin, J.A. Old and new inhibitors of quinone reductase 2. Chem. Biol. Interact. 2010, 186, 103-109. [CrossRef]

58. Leung, K.K.; Shilton, B.H. Binding of DNA-Intercalating Agents to Oxidized and Reduced Quinone Reductase 2. Biochemistry 2015, 54, 7438-7448. [CrossRef] [PubMed]

59. Buryanovskyy, L.; Fu, Y.; Boyd, M.; Ma, Y.; Hsieh, T.C.; Wu, J.M.; Zhang, Z. Crystal structure of quinone reductase 2 in complex with resveratrol. Biochemistry 2004, 43, 11417-11426. [CrossRef] [PubMed]

60. Wu, K.; Knox, R.; Sun, X.Z.; Joseph, P.; Jaiswal, A.K.; Zhang, D.; Deng, P.S.; Chen, S. Catalytic properties of NAD(P)H:quinone oxidoreductase-2 (NQO2), a dihydronicotinamide riboside dependent oxidoreductase. Arch. Biochem. Biophys. 1997, 347, 221-228. [CrossRef] [PubMed]

61. Pegan, S.D.; Sturdy, M.; Ferry, G.; Delagrange, P.; Boutin, J.A.; Mesecar, A.D. X-ray structural studies of quinone reductase 2 nanomolar range inhibitors. Protein Sci. 2011, 20, 1182-1195. [CrossRef] [PubMed]

62. Alghamdi, B.S. The neuroprotective role of melatonin in neurological disorders. J. Neurosci. Res. 2018, 96, 1136-1149. [CrossRef] [PubMed]

63. Qin, X.; Zaki, M.G.; Chen, Z.; Jakova, E.; Ming, Z.; Cayabyab, F.S. Adenosine Signaling and Clathrin-Mediated Endocytosis of Glutamate AMPA Receptors in Delayed Hypoxic Injury in Rat Hippocampus: Role of Casein Kinase 2. Mol. Neurobiol. 2021, 58, 1932-1951. [CrossRef] [PubMed]

64. Singh, N.; Agrawal, M.; Dore, S. Neuroprotective properties and mechanisms of resveratrol in in vitro and in vivo experimental cerebral stroke models. ACS Chem. Neurosci. 2013, 4, 1151-1162. [CrossRef]

65. Costa, L.G.; Garrick, J.M.; Roque, P.J.; Pellacani, C. Mechanisms of Neuroprotection by Quercetin: Counteracting Oxidative Stress and More. Oxidat. Med. Cell. Longev. 2016, 2016, 2986796. [CrossRef] [PubMed]

66. Katsouri, L.; Vizcaychipi, M.P.; McArthur, S.; Harrison, I.; Suarez-Calvet, M.; Lleo, A.; Lloyd, D.G.; Ma, D.; Sastre, M. Prazosin, an alpha(1)-adrenoceptor antagonist, prevents memory deterioration in the APP23 transgenic mouse model of Alzheimer's disease. Neurobiol. Aging 2013, 34, 1105-1115. [CrossRef] [PubMed] 
67. Seredenin, S.B.; Voronina, T.A.; Neznamov, G.G.; Blednov Iu, A.; Badyshtov, B.A.; Viglinskaia, I.V.; Kozlovskaia, M.M.; Kolotilinskaia, N.V.; Iarkova, M.A.; Savel'ev, V.L.; et al. The pharmacogenetic concept of the anxio-selective effect. Vestn. Ross. Akad. Med. Nauk 1998, 11, 3-9.

68. Seredenin, S.B.; Voronin, M.V. Neuroreceptor mechanisms of the afobazole effect. Eksperimental'naia I Klin. Farmakol. 2009, 72, 3-11. [CrossRef]

69. Seredenin, S.B.; Viglinskaia, A.O.; Mozhaeva, T.; Kolyvanov, G.B.; Litvin, A.A.; Avdiunina, N.I.; Savel'ev, V.L.; Zgerdev, V.P. Afobazole metabolism in rats. Eksperimental'naia I Klin. Farmakol. 2008, 71, 50-52. [CrossRef]

70. Seredenin, S.B.; Viglinskaia, A.O.; Kolyvanov, G.B.; Litvin, A.A.; Kravtsova, O.; Zherdev, V.P. Pharmacokinetics of afobazole in rats. Eksperimental'naia I Klin. Farmakol. 2007, 70, 59-64. [CrossRef]

71. Kadnikov, I.A.; Voronin, M.V.; Seredenin, S.B. Afobazole metabolite M-11 inhibits quinone reductase 2. Farmakokinet. I Farm. 2018, 3, 27-30. [CrossRef]

72. Kadnikov, I.A.; Voronin, M.V.; Seredenin, S.B. Cytoprotective Effect of Afobazole and Its Main Metabolite M-11. Bull. Exp. Biol. Med. 2015, 159, 44-47. [CrossRef] [PubMed]

73. Voronin, M.V.; Kadnikov, I.A. Contribution of Sigma-1 receptor to cytoprotective effect of afobazole. Pharmacol. Res. Perspect. 2016, 4, e00273. [CrossRef] [PubMed]

74. Kadnikov, I.A.; Voronkov, D.N.; Voronin, M.V.; Seredenin, S.B. Analysis of Quinone Reductase 2 Implication in Mechanism of Antiparkinsonian Action of Afobazole. Neurochem. J. 2020, 14, 227-234. [CrossRef]

75. Vasiliou, V.; Ross, D.; Nebert, D.W. Update of the NAD(P)H:quinone oxidoreductase (NQO) gene family. Hum. Genom. 2006, 2, 329-335. [CrossRef] [PubMed]

76. Collins, A.R. Measuring oxidative damage to DNA and its repair with the comet assay. Biochim. Et Biophys. Acta 2014, 1840, 794-800. [CrossRef]

77. Fang, L.; Neutzner, A.; Turtschi, S.; Flammer, J.; Mozaffarieh, M. Comet assay as an indirect measure of systemic oxidative stress. J. Vis. Exp. JoVE 2015, 99, e52763. [CrossRef] [PubMed]

78. Pu, X.; Wang, Z.; Klaunig, J.E. Alkaline Comet Assay for Assessing DNA Damage in Individual Cells. Curr Protoc Toxicol. 2015, 65, 3.12.1-3.12.11. [CrossRef]

79. Lorenzo, Y.; Costa, S.; Collins, A.R.; Azqueta, A. The comet assay, DNA damage, DNA repair and cytotoxicity: Hedgehogs are not always dead. Mutagenesis 2013, 28, 427-432. [CrossRef] [PubMed]

80. Zhanataev, A.K.; Anisina, E.A.; Chayka, Z.V.; Miroshkina, I.A.; Durnev, A.D. The phenomenon of atypical DNA comets. Cell Tissue Biol. 2017, 11, 286-292. [CrossRef]

81. Boutin, J.A.; Bouillaud, F.; Janda, E.; Gacsalyi, I.; Guillaumet, G.; Hirsch, E.C.; Kane, D.A.; Nepveu, F.; Reybier, K.; Dupuis, P.; et al. S29434, a Quinone Reductase 2 Inhibitor: Main Biochemical and Cellular Characterization. Mol. Pharmacol. 2019, 95, 269-285. [CrossRef] [PubMed]

82. Chomarat, P.; Coge, F.; Guenin, S.P.; Mailliet, F.; Vella, F.; Mallet, C.; Giraudet, S.; Nagel, N.; Leonce, S.; Ferry, G.; et al. Cellular knock-down of quinone reductase 2: A laborious road to successful inhibition by RNA interference. Biochimie 2007, 89, 1264-1275. [CrossRef]

83. Park, S.Y.; Jung, W.J.; Kang, J.S.; Kim, C.M.; Park, G.; Choi, Y.W. Neuroprotective effects of alpha-iso-cubebene against glutamateinduced damage in the HT22 hippocampal neuronal cell line. Int. J. Mol. Med. 2015, 35, 525-532. [CrossRef]

84. Reinhardt, C.R.; Hu, Q.H.; Bresnahan, C.G.; Hati, S.; Bhattacharyya, S. Cyclic Changes in Active Site Polarization and Dynamics Drive the 'Ping-pong' Kinetics in NRH:Quinone Oxidoreductase 2: An Insight from QM/MM Simulations. ACS Catal. 2018, 8, 12015-12029. [CrossRef] [PubMed]

85. Fu, Y.; Buryanovskyy, L.; Zhang, Z. Crystal structure of quinone reductase 2 in complex with cancer prodrug CB1954. Biochem. Biophys. Res. Commun. 2005, 336, 332-338. [CrossRef]

86. Foster, C.E.; Bianchet, M.A.; Talalay, P.; Faig, M.; Amzel, L.M. Structures of mammalian cytosolic quinone reductases. Free Radic. Biol. Med. 2000, 29, 241-245. [CrossRef]

87. Reybier, K.; Perio, P.; Ferry, G.; Bouajila, J.; Delagrange, P.; Boutin, J.A.; Nepveu, F. Insights into the redox cycle of human quinone reductase 2. Free Radic. Res. 2011, 45, 1184-1195. [CrossRef] [PubMed]

88. Bisaglia, M.; Soriano, M.E.; Arduini, I.; Mammi, S.; Bubacco, L. Molecular characterization of dopamine-derived quinones reactivity toward NADH and glutathione: Implications for mitochondrial dysfunction in Parkinson disease. Biochim. Et Biophys. Acta 2010, 1802, 699-706. [CrossRef] [PubMed]

89. Costa, V.M.; Silva, R.; Ferreira, L.M.; Branco, P.S.; Carvalho, F.; Bastos, M.L.; Carvalho, R.A.; Carvalho, M.; Remiao, F. Oxidation process of adrenaline in freshly isolated rat cardiomyocytes: Formation of adrenochrome, quinoproteins, and GSH adduct. Chem. Res. Toxicol. 2007, 20, 1183-1191. [CrossRef] [PubMed]

90. Hayat, F.; Sonavane, M.; Makarov, M.V. The Biochemical Pathways of Nicotinamide-Derived Pyridones. Int. J. Mol. Sci. 2021, 22, 1145. [CrossRef]

91. Pyle, J.R.; Sy Piecco, K.W.E.; Vicente, J.R.; Chen, J. In Situ Sensing of Reactive Oxygen Species on Dye-Stained Single DNA Molecules under Illumination. Langmuir 2019, 35, 11308-11314. [CrossRef]

92. Thermo Fisher Scientific Catalog. Available online: https://www.thermofisher.com/order/catalog/product/C6827?SID=srchsrp-C6827 (accessed on 1 December 2021). 
93. Choi, H.; Yang, Z.; Weisshaar, J.C. Single-cell, real-time detection of oxidative stress induced in Escherichia coli by the antimicrobial peptide CM15. Proc. Natl. Acad. Sci. USA 2015, 112, E303-E310. [CrossRef]

94. McBee, M.E.; Chionh, Y.H.; Sharaf, M.L.; Ho, P.; Cai, M.W.; Dedon, P.C. Production of Superoxide in Bacteria Is Stress- and Cell State-Dependent: A Gating-Optimized Flow Cytometry Method that Minimizes ROS Measurement Artifacts with Fluorescent Dyes. Front. Microbiol. 2017, 8, 459. [CrossRef] [PubMed]

95. Koppen, G.; Azqueta, A.; Pourrut, B.; Brunborg, G.; Collins, A.R.; Langie, S.A.S. The next three decades of the comet assay: A report of the 11th International Comet Assay Workshop. Mutagenesis 2017, 32, 397-408. [CrossRef]

96. Milena, R.; Ninoslav, Đ.; Jevrosima, S.; Marko, A.; Stoimir, K.; Stefan, D.; Zoran, S. The Investigation of DNA Damage Induced by Adrenaline in Human Lymphocytes In Vitro/Ispitivanja Oštećenja DNK Izazvanih Adrenalinom U Limfocitima Čoveka In Vitro. Acta Vet. 2014, 64, 281-292. [CrossRef]

97. Ueda, K.; Okamoto, Y.; Aoki, A.; Jinno, H. Catecholamine oxidation-mediated transcriptional inhibition in Mn neurotoxicity. J. Toxicol. Sci. 2020, 45, 619-624. [CrossRef] [PubMed]

98. Woods, J.A.; Young, A.J.; Gilmore, I.T.; Morris, A.; Bilton, R.F. Measurement of menadione-mediated DNA damage in human lymphocytes using the comet assay. Free Radic. Res. 1997, 26, 113-124. [CrossRef] [PubMed]

99. Zhou, Q.; Hulea, S.; Kummerow, F.A. Effects of adrenochrome and epinephrine on human arterial endothelial cells in vitro. Res. Commun. Mol. Pathol. Pharmacol. 1995, 89, 111-126.

100. Janda, E.; Parafati, M.; Aprigliano, S.; Carresi, C.; Visalli, V.; Sacco, I.; Ventrice, D.; Mega, T.; Vadala, N.; Rinaldi, S.; et al. The antidote effect of quinone oxidoreductase 2 inhibitor against paraquat-induced toxicity in vitro and in vivo. Br. J. Pharmacol. 2013, 168, 46-59. [CrossRef]

101. Singh, A.; Kukreti, R.; Saso, L.; Kukreti, S. Oxidative Stress: A Key Modulator in Neurodegenerative Diseases. Molecules 2019, 24, 1583. [CrossRef] [PubMed]

102. Coppede, F.; Migliore, L. DNA damage in neurodegenerative diseases. Mutat. Res. 2015, 776, 84-97. [CrossRef] [PubMed]

103. Iskander, K.; Li, J.; Han, S.; Zheng, B.; Jaiswal, A.K. NQO1 and NQO2 regulation of humoral immunity and autoimmunity. J. Biol. Chem. 2006, 281, 30917-30924. [CrossRef] [PubMed]

104. Long, D.J.; Iskander, K.; Gaikwad, A.; Arin, M.; Roop, D.R.; Knox, R.; Barrios, R.; Jaiswal, A.K. Disruption of dihydronicotinamide riboside:quinone oxidoreductase 2 (NQO2) leads to myeloid hyperplasia of bone marrow and decreased sensitivity to menadione toxicity. J. Biol. Chem. 2002, 277, 46131-46139. [CrossRef]

105. Janda, E.; Lascala, A.; Carresi, C.; Parafati, M.; Aprigliano, S.; Russo, V.; Savoia, C.; Ziviani, E.; Musolino, V.; Morani, F.; et al. Parkinsonian toxin-induced oxidative stress inhibits basal autophagy in astrocytes via NQO2/quinone oxidoreductase 2 : Implications for neuroprotection. Autophagy 2015, 11, 1063-1080. [CrossRef] [PubMed]

106. Benoit, C.E.; Bastianetto, S.; Brouillette, J.; Tse, Y.; Boutin, J.A.; Delagrange, P.; Wong, T.; Sarret, P.; Quirion, R. Loss of quinone reductase 2 function selectively facilitates learning behaviors. J. Neurosci. 2010, 30, 12690-12700. [CrossRef]

107. Hashimoto, T.; Nakai, M. Increased hippocampal quinone reductase 2 in Alzheimer's disease. Neurosci. Lett. 2011, 502, 10-12. [CrossRef]

108. Wang, W.; Le, W.D.; Pan, T.; Stringer, J.L.; Jaiswal, A.K. Association of NRH:quinone oxidoreductase 2 gene promoter polymorphism with higher gene expression and increased susceptibility to Parkinson's disease. J. Gerontol. A Biol. Sci. Med. Sci. 2008, 63, 127-134. [CrossRef] [PubMed]

109. Mozhaeva, T.Y.; Yarkova, M.A.; Lezina, V.P.; Seredenin, S.B. Synthesis and pharmacological activity of the main metabolite of afobazole and its analogs. Pharm. Chem. J. 2011, 45, 147. [CrossRef]

110. Wiegant, F.A.C.; Limandjaja, G.; de Poot, S.A.H.; Bayda, L.A.; Vorontsova, O.N.; Zenina, T.A.; Langelaar-Makkinje, M.; Post, J.A.; Wikman, G. Plant adaptogens activate cellular adaptive mechanisms by causing mild damage. In Adaptation Biology and Medicine: Health Potentials; Lukyanova, L., Takeda, N., Singal, P.K., Eds.; Narosa Publishers: New Dehli, India, 2008; Volume 5, pp. 319-332.

111. GOST 33215-2014. Guidelines for Accommodation and Care of Animals. Environment, Housing and Management. In Interstate Counsil for Standartization, Metrology and Certification; Standartinform: Moscow, Russia, 2016; Available online: https: / protect. gost.ru/document.aspx?control=7\&id=202494 (accessed on 1 December 2021).

112. National Research Council (U.S.); Committee for the Update of the Guide for the Care and Use of Laboratory Animals; Institute for Laboratory Animal Research (U.S.); National Academies Press (U.S.). Guide for the Care and Use of Laboratory Animals, 8th ed.; National Academies Press: Washington, DC, USA, 2011; p. 220.

113. Ross, D.; Siegel, D. The diverse functionality of NQO1 and its roles in redox control. Redox Biol. 2021, 41, 101950. [CrossRef] [PubMed] 